\title{
Mechanisms by which HPV Induces a Replication Competent Environment in Differentiating Keratinocytes
}

\author{
Cary A. Moody ${ }^{1,2}$ \\ 1 Department of Microbiology and Immunology, University of North Carolina at Chapel Hill, Chapel Hill, \\ NC 27599, USA; camoody@med.unc.edu \\ 2 Lineberger Comprehensive Cancer Center, University of North Carolina at Chapel Hill, Chapel Hill, \\ NC 27599, USA
}

Received: 31 August 2017; Accepted: 15 September 2017; Published: 19 September 2017

\begin{abstract}
Human papillomaviruses (HPV) are the causative agents of cervical cancer and are also associated with other genital malignancies, as well as an increasing number of head and neck cancers. HPVs have evolved their life cycle to contend with the different cell states found in the stratified epithelium. Initial infection and viral genome maintenance occurs in the proliferating basal cells of the stratified epithelium, where cellular replication machinery is abundant. However, the productive phase of the viral life cycle, including productive replication, late gene expression and virion production, occurs upon epithelial differentiation, in cells that normally exit the cell cycle. This review outlines how HPV interfaces with specific cellular signaling pathways and factors to provide a replication-competent environment in differentiating cells.
\end{abstract}

Keywords: virus; HPV; cell cycle; differentiation; replication; DNA damage response

\section{Introduction}

Human papillomaviruses (HPV) are non-enveloped, small DNA viruses that exhibit a strict tropism for epithelial cells. Over 200 types of HPVs have been identified and are classified into five evolutionary genera $(\alpha, \beta, \gamma, \mu, v)$ based on DNA sequence similarity [1]. The alpha group is the largest, containing approximately $64 \mathrm{HPV}$ types, and is divided based on tropism of each type for cutaneous or mucosal epithelium. The cutaneous types cause common warts, which are rarely associated with malignancy [2]. About 40 alpha HPVs infect the mucosal epithelium and are categorized as high-risk or low-risk based on their association with cancer [1,3]. Low-risk types (e.g., HPV11 and HPV6) are most commonly associated with benign genital warts, but are also implicated in the development of laryngeal papillomas. The fifteen types termed high-risk $(16,18,31,33,35,39,45,51,51,56,58,59,68$, $73,82)$ are classified as oncogenic based on their association with anogenital cancers [4]. In addition, certain high-risk types, particularly HPV16, infect the oropharyngeal mucosa and are associated with an increasing number of head and neck cancers [5]. Beta HPVs exhibit a tropism for the cutaneous epithelium, with infection occurring early in life and typically producing an asymptomatic infection [6]. However, persistent infection with certain types of beta HPVs are associated with the development of non-melanoma skin cancers at sun exposed sites, particularly in immunosuppressed patients and patients with the rare disease epidermodysplasia verruciformis [7]. The mu, nu and gamma HPVs infect the cutaneous epithelium and are most commonly associated with the formation of benign papillomas [8]. 


\section{HPV Life Cycle}

The life cycle of HPV is intimately linked to the differentiation status of the host cell keratinocyte and is characterized by three distinct phases of replication $[9,10]$ (Figure 1). High-risk and low-risk HPVs initiate infection by gaining access to the proliferating basal cells of the stratified epithelium through a microwound [11]. Upon entry, HPV undergoes a transient round of replication referred to as "establishment replication", which results in a copy number of 50-100 viral genomes per cell. Viral episomes are subsequently maintained in the undifferentiated basal cells by replicating along with the host cell chromosomes. Only upon epithelial differentiation is the productive phase of the viral life cycle activated, resulting in the amplification of viral genomes to thousands of viral copies per cell in the suprabasal layers, as well as activation of late gene expression and virion assembly and release $[10,12]$. Regulation of the viral life cycle in this manner allows HPV to avoid detection by the immune response as high levels of viral gene expression as well as virion production are restricted to the uppermost layers of the epithelium, which are not under immune surveillance [4].

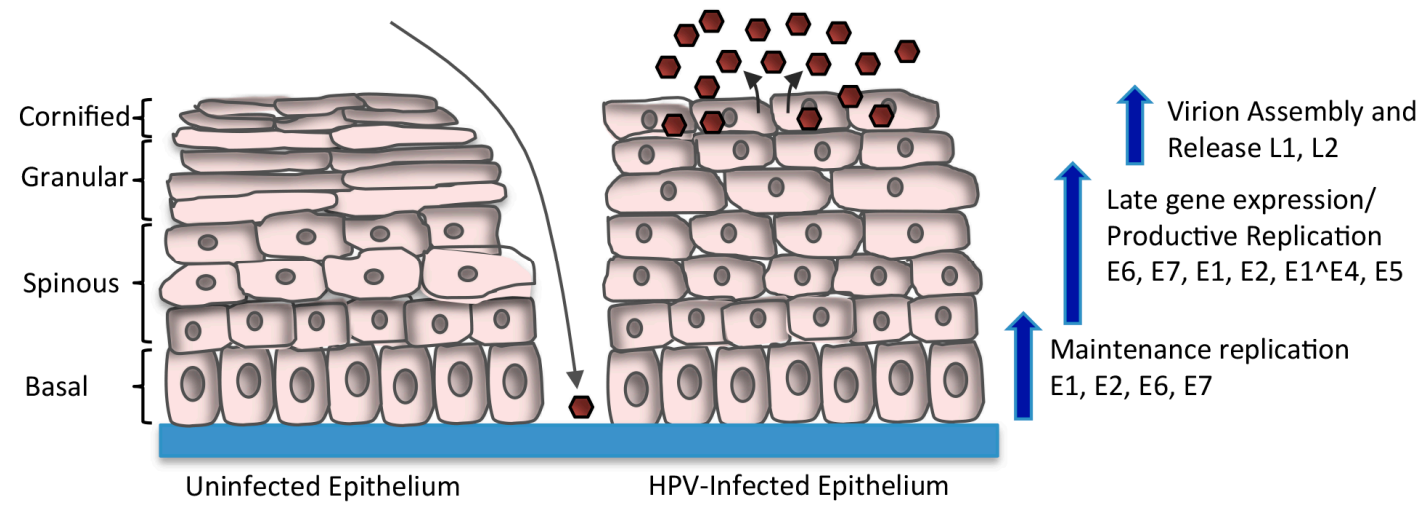

Figure 1. Human papillomavirus (HPV) Life Cycle. HPV infects the basal layer of the stratified epithelium through a microwound. Upon entry into the cell, the virus transiently amplifies to 50-100 copies per cell. HPV genomes are maintained at a stable copy number in undifferentiated basal cells by replicating along with cellular DNA. Upon differentiation, the productive phase of the life cycle is activated, resulting in late gene expression and amplification of viral genomes to thousands of copies per cell. The expression of E6 and E7 allows for cell cycle re-entry upon differentiation, providing cellular factors for productive replication. E4 and E5 also contribute to efficient productive replication. Expression of L1 and L2 promotes the encapsidation of newly replicated genomes, resulting in virion release from the uppermost layers of the epithelium (brown hexagons).

Due to the small coding capacity of the viral genome, HPV depends on the host DNA replication machinery to synthesize its DNA. While readily available in undifferentiated cells to stably maintain viral episomes, epithelial differentiation normally results in an exit from the cell cycle, limiting the availability of replication machinery in post-mitotic cells [13]. This provides a conundrum for HPV since differentiation is required to activate the productive phase of the life cycle, yet HPV also depends on cellular factors for replication. To support productive replication, HPV employs numerous mechanisms to subvert key regulatory pathways that regulate host cell replication, in turn maintaining differentiating cells active in the cell cycle. As such, HPV is able to reactivate cellular genes and signaling pathways necessary to support late gene expression and amplification of viral DNA. The majority of our insights into productive HPV replication have emerged from studying the alpha HPV types, primarily the high-risk types HPV16, HPV18 and HPV31. This review will focus on the mechanisms by which alpha HPVs renders post-mitotic, differentiating cells permissive for DNA synthesis during the productive phase of the viral life cycle. 


\section{HPV Genome Organization}

The HPV genome exists as a covalently closed circle (episome) of approximately $8 \mathrm{~kb}$ [8]. HPV genomes are histone-associated in the virion as well as in infected cells, exhibiting a nucleosomal pattern similar to that of cellular DNA [14,15]. HPV genomes contain six to eight open reading frames (ORF) that are expressed as polycistronic transcripts that are then alternatively spliced to yield individual gene products $[16,17]$ (Figure 2). High-risk HPV genomes contain two main promoters that are active at different stages in the viral life cycle [18-20]. In undifferentiated epithelial cells, viral gene expression is regulated by the early promoter, which is located adjacent to the E6 ORF in the upstream regulatory region (URR) and is referred to as p97 for HPV16 and HPV31, and p105 for HPV18. The early promoter directs expression of E1 and E2, which is necessary for viral replication. E1 is an ATP-dependent helicase that facilitates unwinding of the viral DNA and also recruits cellular factors to the viral origin of replication, located in the URR [21]. E2 is a sequence-specific DNA binding protein that has multiple binding sites in the URR. E2 binds and recruits E1 to a specific E1 binding site in the viral origin. E2 also regulates viral gene expression from the early promoter. In addition, E2 contributes to episomal maintenance in undifferentiated cells by tethering viral genomes to host mitotic chromosomes [22]. E6 and E7, which are the oncoproteins for the high-risk HPV types, are also expressed from the early promoter. E6 and E7 contribute to viral replication through their ability to modulate cell cycle control, cell survival, cellular differentiation, immune evasion, as well as DNA damage responses [23-27]. E1^E4 is encoded by a spliced RNA that fuses the first five amino acids of the E1 ORF with E4 [28]. While E1^E4 and E5 are expressed at low levels from the early promoter in undifferentiated cells, the high-risk E4 and E5 proteins seem to be primarily involved in facilitating efficient productive replication in differentiating cells [29-33]. Some HPV types express a fusion of E8 and the C-terminal half of the E2 ORF (E8^E2), which initiates from a promoter in the E1 ORF and functions to limit viral replication and transcription in undifferentiated and differentiated cells [34]. The late promoter is located in the E7 ORF (p742 HPV31, p811 HPV18, p670 HPV16) and is activated upon epithelial differentiation [35-37]. The late promoter is not regulated by E2 and drives high levels of expression of E1 and E2, as well as E1^E4 and E5 to facilitate productive viral replication. In addition, the late promoter directs expression of the L1 and L2 capsid genes to allow for encapsidation of viral genomes in the uppermost layers of the epithelium.

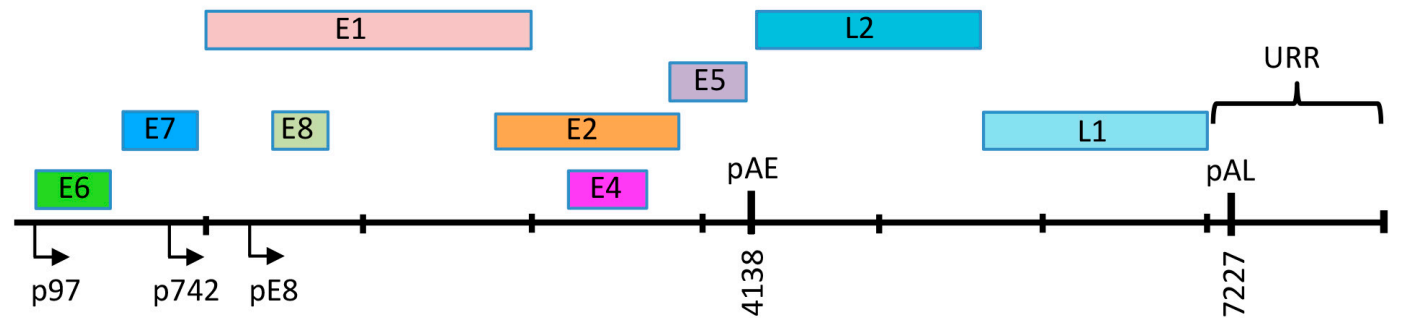

Figure 2. Linear depiction of the HPV31 genome. The open reading frames (ORF) are indicated by the color blocks. The early promoter is located upstream of the E6 ORF (p97) and the late promoter is located in the E7 ORF (p742). E8^E2 is expressed from a promoter located in the E1 ORF (pE8). The early polyadenylation site is located at the $3^{\prime}$ end of the E5 ORF (pAE) and the late polyadenylation site (pAL) is located in the URR (Upstream Regulatory Region). The origin of replication, as well as E1 and E2 binding sites are also located in the URR.

\section{Regulation of Viral Gene Expression upon Keratinocyte Differentiation}

Efficient amplification of HPV genomes upon differentiation requires activation of the late promoter to provide increased levels of E1, E2, E1^E4 and E5 [10]. The early promoter remains active upon differentiation, directing expression of E6 and E7, which is also necessary for late viral events. The tight link between differentiation and late gene expression suggests that differentiation-specific factors are required for late promoter activation. Chromatin rearrangements and histone modifications are 
detected at the late promoter upon differentiation, though how this is regulated remains unclear $[38,39]$. A variety of transcription factors have been shown to bind to the late promoter in the context of complete, episomal genomes, both in undifferentiated and differentiated cells, including c-Myb, C/EBP $\alpha$, C/EBP $\beta$, NFAT (Nuclear Factor of Activated T-cells), YY1 (Yin Yang 1), NF1 (Nuclear Factor 1), Oct-1 (Octamer-binding transcription factor 1), c-Jun, and Sp1 (Specificity Protein 1) [38,40]. However, only the LIP (Liver-enriched Inhibitory Protein) and LAP (Liver-enriched Activator Protein) isoforms of $\mathrm{C} / \mathrm{EBP} \alpha$ have been shown to regulate late promoter activity [41]. More recent studies have shown that transcription elongation regulates late promoter activity through the recruitment of elongation mediators (e.g., CDK8, BRD4) to viral genomes upon differentiation [42]. Late gene expression is also regulated by alternative splicing and changes in polyadenylation site usage [16]. Upon differentiation, read-through of the early polyadenylation site (pAE) located at the end of the E5 ORF allows late transcripts to be polyadenylated at the late polyadenylation (pAL) site located in the URR, facilitating expression of L1 and L2. Transcriptional read-through may be influenced by E2 expression, which increases in the mid to upper epithelial layers of the epithelium and has been shown to repress polyadenylation at the early site [43-45]. Polyadenylation is co-transcriptionally regulated with splicing, and certain splicing factors have been shown to influence polyadenylation site usage for HPV16 [46,47]. Splicing of HPV transcripts is positively regulated by Serine Arginine splicing factors (SRSF) (e.g., SRSF1, SRSF2, SRSF3), which increase upon differentiation and are regulated transcriptionally by E2 [46,48]. SRSF9 has also been shown to increase the efficiency of late RNA splicing [49]. Studies by the Parish lab recently demonstrated that CTCF insulator proteins regulate viral transcript splicing upon differentiation through binding to the HPV18 E2 ORF [50]. Mutation of the E2 CTCF binding site in the context of the HPV18 genome results in increased levels of E6 and E7 and increased proliferative capacity in suprabasal cells [50]. The E2 CTCF binding site is conserved across high-risk types, suggesting that HPV has evolved CTCF recruitment to viral genomes to control the levels of E6 and E7 upon differentiation, possibly to facilitate eventual exit from the cell cycle to allow for virion assembly and release.

\section{Maintenance of Proliferative Potential in Differentiating Cells}

\subsection{Disruption of Rb/E2F Complexes}

As normal, uninfected cells leave the basal layer, they lose proliferative potential and begin a terminal differentiation program [13]. However, a fundamentally important aspect of the HPV life cycle is to maintain cell cycle competence in differentiating epithelial cells to provide cellular factors for productive replication. E7 plays a critical role in this process though the binding and targeted degradation of the tumor suppressor $\mathrm{pRb}$, as well as the related pocket proteins p107 and p130 [51] (Figure 3). Rb family members regulate the G1 to S-phase transition by controlling the activity of E2F transcription factors [52]. E7 binds to Rb family members through a conserved LXCXE domain located in the extreme $\mathrm{C}$-terminus that disrupts the interaction between $\mathrm{Rb}$ and $\mathrm{E} 2 \mathrm{~F}$ transcription factors [53,54]. Disruption of the Rb/E2F interaction results in constitutive activation of E2F-resposive genes, allowing E7 to push differentiating cells back into S-phase, disrupting suprabasal quiescence and reactivating cellular DNA synthesis [55-58]. As a result, suprabasal cells exhibit markers of differentiation, as well as markers of cell cycle re-entry, including PCNA, cyclin A and cyclin E [55,59]. Low-risk E7 proteins also bind pRb, p107 and p130, but with much lower affinity, and only target p130 for degradation $[53,60,61]$. The loss of E7 expression in the context of HPV16 infection prevents the induction of host cell replication machinery and productive viral replication in suprabasal epithelial cells of organotypic raft cultures, which recapitulate the three-dimensional architecture of the stratified epithelium [62,63]. These studies highlight the importance of E7 in differentiation-dependent viral events. In addition to $\mathrm{Rb}$ family members, the interaction between $\mathrm{E} 7$ and type 1 histone deacetylases (HDAC1-3) is also important in maintaining E2F activation upon differentiation and facilitating viral replication [64-66]. HPV31 E7 specifically increases the levels of E2F2 by preventing HDAC binding to 
the $e 2 f 2$ promoter [65]. The increase in E2F2 is necessary for productive viral replication, though the downstream targets of $\mathrm{E} 2 \mathrm{~F} 2$ have not yet been identified.

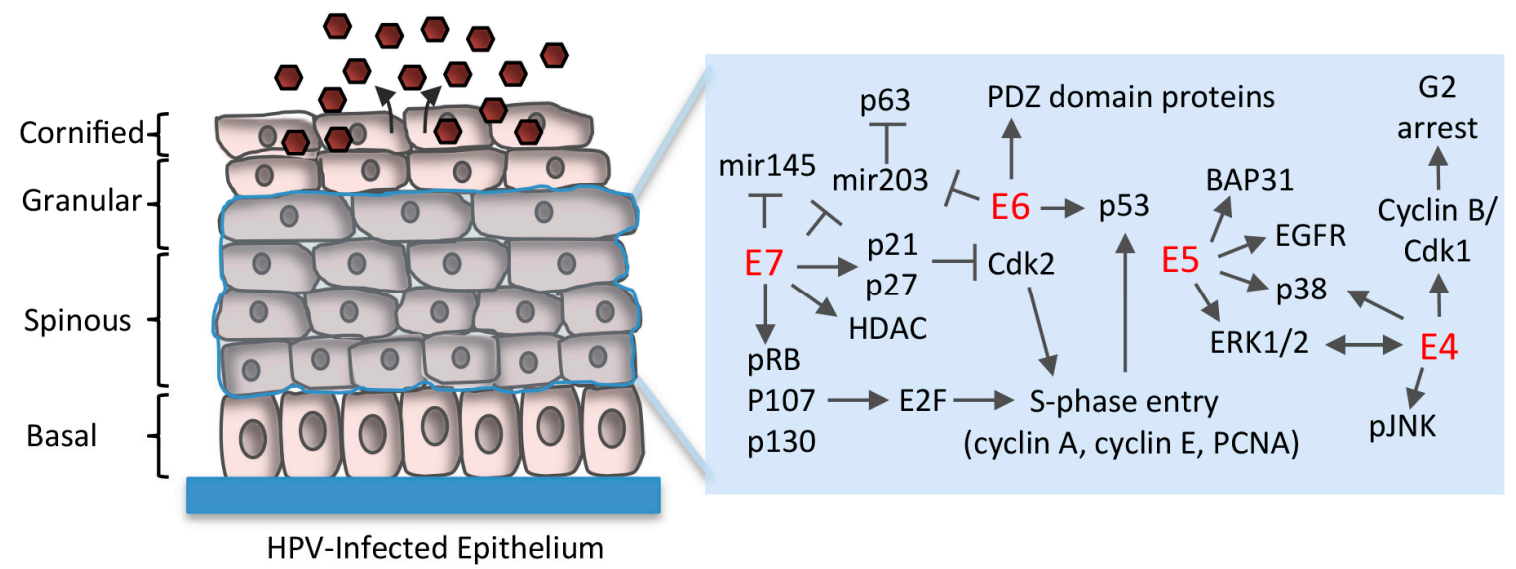

Figure 3. Cellular factors targeted by HPV proteins to maintain cell cycle competency in suprabasal cells. E7 pushes differentiating cells back into the cell cycle by binding to pRb, p107 and p130, which regulate entry into S-phase by negatively regulating E2F transcription factors. Disruption of the $\mathrm{pRb} / \mathrm{E} 2 \mathrm{~F}$ interaction by E7 allows for constitutive activation of E2F-responsive genes, allowing for S-phase re-entry by post-mitotic cells. Unscheduled S-phase entry induced by E7 results in increased p53 that is targeted for degradation by E6 to avoid apoptosis or cell cycle arrest in G1, as well as to block p53's negative effects on productive replication. E5 contributes to productive viral replication by maintaining cell cycle competency upon differentiation through interaction with BAP31, as well as through activation of epidermal growth factor receptor (EGFR), mitogen activated protein kinase (p38MAPK) and extracellular signal-regulated kinase (ERK)1/2. E4 may increase the efficiency of viral genome amplification by sustaining a G2-arrested environment upon differentiation, and through activation of MAPK signaling (p38, ERK1/2, pJNK). T bars indicate inhibition. Arrows indicate activation. HDAC: histone deacetylase; PCNA: proliferating cell nuclear antigen.

\subsection{Uncoupling of Differentiation From Proliferation}

Normal epithelial differentiation results in cell cycle arrest that is carried out by increased expression of the cyclin-dependent kinase inhibitors p21Cip1 and p27Kip1, which inhibits the activity of cyclin-dependent kinase 2 (Cdk2) [67]. Cdk2 facilitates G1 to S-phase entry and progression through interaction with cyclin $\mathrm{E}$ and cyclin A, respectively [68]. To circumvent this potential block, E7 targets cellular molecules that link differentiation with cell cycle exit (Figure 3). E7 does not affect the differentiation-dependent increase in p21, but rather binds to p21, at least in part through its $\mathrm{Rb}$ binding domain, in turn delaying differentiation and blocking the inhibitory effects on Cdk2 activity to establish a proliferative environment $[57,69]$. Low-risk E7 proteins do not bind as efficiently to p21 and are therefore not as successful at mitigating the inhibitory effects of p21 [57]. High-risk E7 proteins also maintain Cdk2 activity through direct interaction with cyclin E and cyclin A, as well as through maintaining high levels of the Cdc25a phosphatase, which removes inhibitory phosphorylation from Cdk2 [70-72]. Cdk2 activity may also contribute to productive viral replication by regulating the cellular localization of the E1 viral helicase. Cdk2-dependent phosphorylation of E1 prevents its nuclear export, leading to accumulation of E1 in the nucleus, which may allow for rapid amplification of viral genomes upon differentiation [73,74]. Proliferative potential in differentiating cells is also maintained by the E5 protein. E5 is expressed at high levels in suprabasal cells and contributes to efficient productive replication of HPV16 and HPV31 [33,75]. Loss of E5 expression in the context of the HPV31 genome results in decreased cyclin A and cyclin B levels upon methylcellulose-induced differentiation and reduces colony formation following differentiation [33]. Colony formation requires E5's ability to interact with B cell associated protein 31 (BAP31), an ER chaperone and regulator of 
apoptosis [76]. However, the mechanism by which this interaction maintains proliferative competence in differentiating cells is currently unclear. E5 also modulates several growth pathways that may contribute to viral genome amplification, including signaling through the epidermal growth factor receptor (EGFR), as well as activation of p38MAPK and ERK1/2 [77].

\subsection{E6 Abrogation of p53 and Targeting of PDZ (PSD95/DLG1/ZO-1) Domain-Containing Proteins}

To facilitate re-entry into the cell cycle and viral genome amplification in suprabasal cells, the activities of E7 coordinate with those of E6 [26] (Figure 3). One of the key functions of E6 is the inactivation of p53. For high-risk types, E6 promotes p53 ubiquitylation and proteasome-dependent degradation through interaction with the E6AP ubiquitin ligase [78-80]. E6-mediated p53 degradation is thought to protect cells from apoptosis or growth arrest due to E7-mediated cell cycle re-entry in the suprabasal layers. However, recent studies indicate that p53 negatively regulates viral genome amplification. E6 mutants in the context of the HPV18 genome that are unable to destabilize p53 result in fewer suprabasal cells supporting viral genome amplification in organotypic raft cultures [81]. The mechanism by which p53 negatively regulates productive viral genome amplification is unclear, but may be through interaction with the $\mathrm{E} 2$ origin binding protein $[82,83]$. E6 proteins also contribute to replication competence through the targeting of specific cellular proteins containing PDZ (PSD95/DLG1/ZO-1) domains [84]. E6 interacts with PDZ proteins through a C-terminal PDZ domain binding motif (PBM) that is found only in high-risk E6 proteins, suggesting this motif serves as a signature for oncogenic potential $[85,86]$. Most of the PDZ proteins that interact with E6 are targeted for proteasome-dependent degradation, or have an altered cellular localization [84]. PDZ proteins shown to associate with E6 are involved in the regulation of cell growth and polarity, as well as signal transduction pathways involved in cell proliferation, apoptosis, migration and intracellular trafficking [84]. The E6 PBM has been shown to play an essential role in viral genome amplification. Human foreskin keratinocytes transfected with HPV18 genomes containing a mutation in the E6 PBM exhibit a loss of productive viral replication and late gene expression in organotypic raft cultures, correlating with a decrease in the number of S-phase competent cells in the suprabasal layer [87]. A role for the E6 PBM in productive replication has also been observed for the high-risk types HPV31 and HPV16 [88,89]. More recent studies demonstrated that the E6 PBM protects the mitotic integrity of keratinocytes containing HPV18 episomes, with loss of the PBM domain leading to mitotic abnormalities that prevents the expansion of suprabasal cells to support vegetative viral replication [90]. What specific PDZ proteins are targeted by E6 to preserve mitotic integrity and to promote viral replication have yet to be defined.

\subsection{Regulation of Differentiation-Induced microRNA Expression}

While the HPV genome does not encode microRNAs, E6 and E7 of high-risk types have been shown to modulate the expression of cellular microRNAs to facilitate viral replication in differentiating cells [91] (Figure 3). microRNA-203 (mir203) is normally induced concomitantly with epithelial differentiation and restricts the proliferative potential of differentiating cells by repressing the expression of the p53 homolog p63 [92]. p63 is required for maintaining proliferative potential and acts as a switch between proliferation and differentiation [93]. Studies from the Laimins lab demonstrated that p63 is required for productive replication of HPV31 [94]. Expression of HPV31 E6 and E7 prevents upregulation of mir203 upon differentiation, which is necessary to maintain p63 in differentiating cells and presumably provide a proliferative environment for productive viral replication [95]. In support of this, knockdown of p63 expression in differentiating HPV31 positive keratinocytes using shRNAs results in decreased levels of cell cycle proteins, including cyclins A, B, and E, as well as Cdc25c, Cdk1 and Cdk2 [94]. mir145 is also normally induced upon differentiation and has been shown to negatively regulate the productive phase of the HPV31 life cycle [96]. mir145 regulates the levels of the transcription factor KLF4 (Kruppel-like factor 4), which is a target gene of p63 that plays a role in proliferation, differentiation, and maintenance of stem cells $[97,98]$. In the stratified 
epithelium, KLF4 also regulates expression of late epidermal differentiation markers and contributes to the formation of the cornified layer. KLF4 is present at high levels upon differentiation in HPV31 positive cells and is necessary for the productive phase of the viral life cycle [99]. HPV31 regulates KLF4 levels transcriptionally by p63, but also post-transcriptionally by E7-mediated suppression of differentiation-induced mir145 expression $[96,99]$. KLF4 levels are also regulated post-translationally by E6's ability to prevent inhibitory phosphorylation and sumoylation of KFL4 [99]. KLF4 directly activates late viral gene expression, and thus productive viral replication, by binding to the HPV31 URR in a complex with BLIMP1. Furthermore, KLF4 expression is necessary to maintain cyclin A and cyclin B in suprabasal cells [99]. KLF4 therefore has multiple functions in promoting the productive phase of the viral life cycle. In addition to KLF4, p63 also regulates expression of the DNA repair factors Rad51 and BRCA2, as well as activation of the checkpoint kinase Chk2 in HPV31 positive keratinocytes [94]. As described in more detail below, Chk2 kinase activity and Rad51 have been shown to be required for productive replication of HPV31 [100,101]. These studies suggest that upon cell cycle re-entry, HPV's ability to modulate differentiation-induced microRNAs results in maintenance of p63 levels, prolonging proliferative potential and ensuring the expression of a subset of cellular genes necessary for productive viral replication as well as late gene expression. In addition, p63 may contribute to activation of the DNA damage response that is necessary for viral DNA synthesis in differentiating cells.

\section{Establishment of a G2-Arrested Environment}

To provide a replication-competent environment upon differentiation, high-risk and low-risk E7 proteins push post-mitotic cells back into the cell cycle, rather than maintaining cells active in S-phase upon differentiation $[102,103]$. E7-induced cell cycle re-entry has traditionally been thought to result in an S-phase environment that provides HPV access to replication machinery that supports productive viral replication. However, more recent studies indicate that productive viral replication occurs post-cellular DNA synthesis in cells that are subsequently arrested in G2 [104-106]. Using organotypic raft cultures of HPV18 positive keratinocytes, Wang et al., demonstrated that cells undergoing viral genome amplification exhibit markers of G2/M arrest, including high levels of cytoplasmic cyclin B1 and inactive cyclin-dependent kinase 1 (Cdk1) [105]. Cdk1 normally forms a complex with cyclin B1 in the nucleus to stimulate entry into mitosis. In addition, these cells also contain the inactive form of the Cdc25C phosphatase, which functions to remove inhibitory phosphorylation from Cdk1 to allow entry into mitosis [107]. Overall, these studies indicate that HPV requires G2 arrest upon differentiation to support the productive phase of the viral life cycle.

The mechanism by which HPV induces G2 arrest upon differentiation is currently unclear. Arrest in G2 typically occurs in response to DNA damage or incomplete replication, which activates the ATM (Ataxia-Telangiectasia Mutated) and ATR (ATM and Rad3-related) DNA damage kinases [108]. ATM and ATR phosphorylate the checkpoint kinases Chk2 and Chk1, leading to their activation and the phosphorylation/inhibition of Cdc25C, preventing activation of the Cdk1/cyclin B1 complex [109]. As discussed below, high-risk HPV positive cells exhibit constitutive activation of ATM and ATR, with activation of both of these pathways necessary for productive viral replication $[100,110,111]$. Inhibition of Chk2 kinase activity in differentiating HPV31 positive cells results in decreased inhibitory phosphorylation of Cdc25C and Cdk1, offering support that activation of the ATM/ATR pathways contributes to the G2 arrest observed upon differentiation [100]. E7 expression alone is sufficient to induce ATM and ATR activation, as well as high levels of cytoplasmic cyclin B and Cdk1 in suprabasal cells of HPV18 organotypic raft cultures, suggesting that E7 is involved in facilitating cell cycle arrest upon differentiation $[100,104,110]$. However, several studies have shown that the overexpression of the E4 protein of multiple HPV types induces G2 arrest [112-114]. This is thought to occur through E4s ability to interact with cyclin $\mathrm{B} / \mathrm{Cdk} 1$ complexes and to promote inhibitory phosphorylation of Cdk1 through the Wee1 kinase $[114,115]$. E1^E4 is the most abundantly expressed viral gene upon differentiation, occurring concomitantly with viral genome amplification due to activation of the late 
promoter [28]. In addition, HPV16 E4 protein stability is increased upon phosphorylation by ERK1/2, leading to high levels of E4 protein in differentiating cells [116]. E1^Е4 expression has been shown to be necessary for efficient productive replication of HPV16, HPV18 and HPV31, but not for low-risk HPV11 [30-32,106]. Studies using normal immortalized keratinocytes containing HPV16 E4 mutants that no longer induce G2 arrest exhibit decreased viral genome amplification and L1 gene expression upon differentiation in methylcellulose, as well as in organotypic raft cultures [29]. These studies indicate that the $\mathrm{G} 2$ arrest function of $\mathrm{E} 4$ contributes to providing a replication-competent environment. The accumulation of E4 in G2 arrested cells may foster productive replication by enhancing the accumulation of E1 in the nucleus, possibly through activation of MAPK pathways that activate E1's nuclear localization sequence $[29,117,118]$. E4 has been proposed to induce $G 2$ arrest to counteract E7-induced proliferation in order to establish an environment that allows for rapid amplification of viral genomes. It is possible that E7 initiates G2 arrest following cell cycle re-entry through activation of ATM and ATR, but increased E4 protein levels sustain G2 arrest, providing an environment conducive to productive viral replication. Productive replication in a G2 arrested environment is postulated to allow HPV to avoid competition with host DNA synthesis and appropriate necessary cellular factors for amplification of its genomes. E2 may contribute to this process through interaction with the cellular replication protein ORC2 (origin recognition complex), which promotes assembly of pre-replication (pre-RC) complexes on mammalian origins. Overexpression of HPV31 or HPV16 E2 decreases ORC2 occupancy at mammalian origins [119], raising the possibility that increased levels of E2 upon differentiation may serve to restrict pre-RC assembly at cellular origins that could compete with HPV for access to host replication machinery. This is important considering that increasing evidence supports a role for homologous recombination (HR) DNA repair pathways in the amplification of HPV genomes (discussed below) [25,120]. HR activity is restricted to the S- and G2-phases of the cell cycle [121]. By productively replicating post-cellular DNA synthesis in a G2 arrested environment, HPV has unfettered access to DNA repair factors, as well as other cellular factors, that are necessary for viral DNA synthesis.

\section{Use of DNA Damage Response Pathways for Productive Replication}

Numerous studies over the past several years have provided evidence to support a role for the DNA damage response (DDR) in productive replication of high-risk alpha HPV types [25]. The DDR is a complex series of signaling events that act to coordinate the cell cycle with DNA repair. There are three main kinases activated in response to DNA damage; ATM, ATR and DNA-PK (DNA-dependent Protein Kinase), all of which belong to the PIK-like kinase (Phosphatidyl inositol 3' kinase) family of serine/threonine kinases [122]. ATM and DNA-PK respond primarily to double-strand DNA breaks (DSBs) and promote repair through high fidelity homologous recombination (HR), or error prone non-homologous end joining (NHEJ), respectively [121] (Figure 4). In contrast, ATR facilitates repair of single-strand DNA that is generated in response to replication stress, or during the processing of DSBs [123] (Figure 4). However, due to the complexity of DNA repair, there is considerable cross-talk between these pathways to maintain genomic integrity. HPV requires activation of the ATM and ATR response pathways for productive viral replication, however whether the DNA-PK pathway also contributes to viral replication is not yet known. Activation of the DDR provides HPV access to the necessary repair factors that play a direct role in viral DNA synthesis. In addition, increasing evidence suggests that HPV utilizes these pathways to establish a G2 arrested environment that is amenable to recombination-directed amplification of viral genomes. 


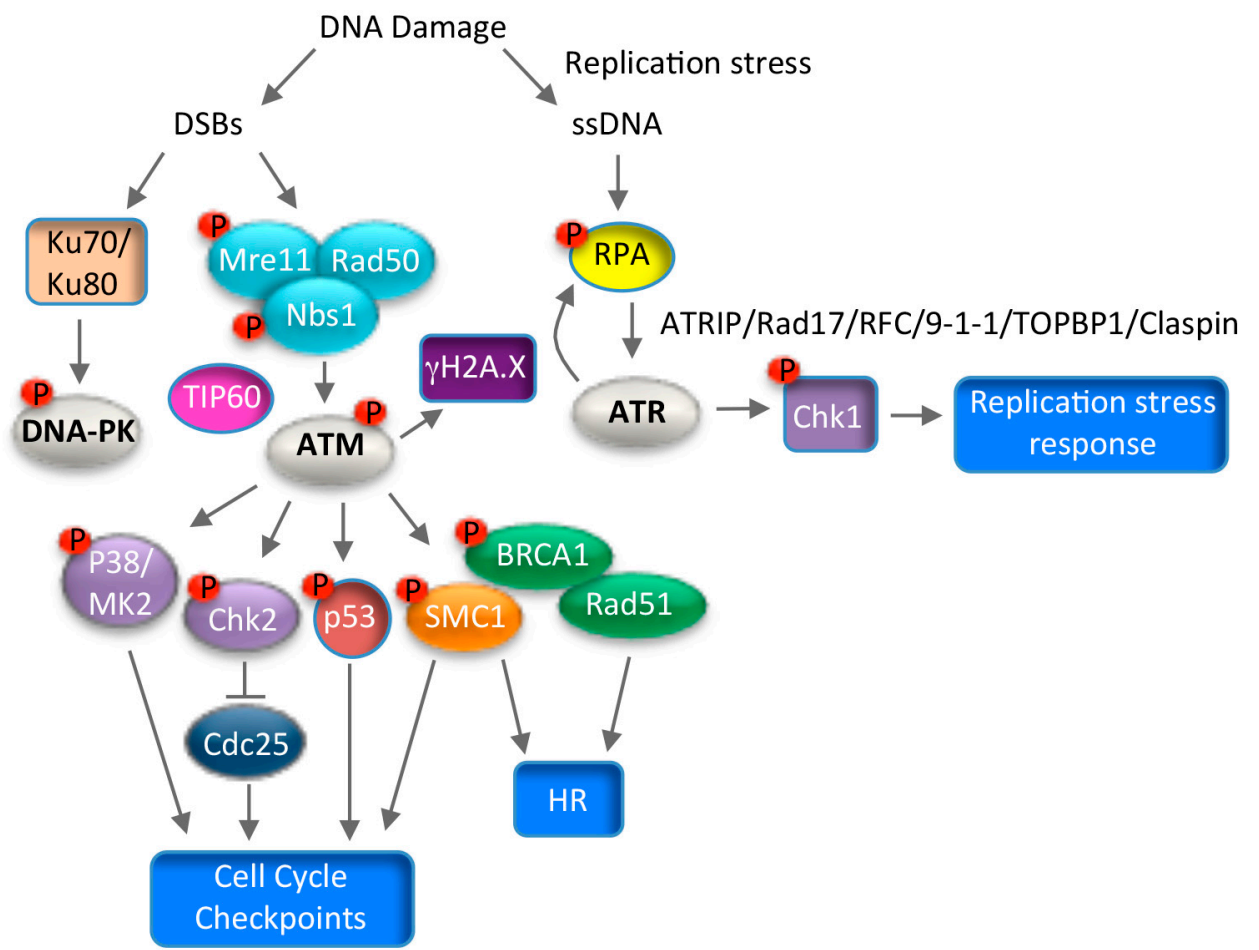

Figure 4. Schematic of the Ataxia-Telangiectasia Mutated (ATM), DNA-dependent Protein Kinase (DNA-PK), and ATM and Rad3-related (ATR) DNA damage response pathways. ATM and DNA-PK are activated in response to double strand DNA breaks (DSBs). ATM facilitates DNA repair through high-fidelity homologous recombination (HR), however, DNA-PK promotes repair through error-prone non-homologous end joining (NHEJ). DNA-PK is activated by the DNA damage sensor complex of $\mathrm{Ku} 70 / \mathrm{Ku} 80$, while ATM is activated by the DNA damage sensor complex MRN (Mre11, Rad50, Nbs1) and the TIP60 acetyltransferase. ATM phosphorylates numerous downstream effectors, including H2A.X (gH2AX), Chk2, p38, p53, SMC1 and Breast Cancer Gene 1 (BRCA1) to induce cell cycle arrest and facilitate DNA repair, or to promote apoptosis in the case of severe DNA damage. ATR is activated by single-stranded DNA (ssDNA) generated by replication stress or the resection of DSBs. ssDNA is protected by the tripartite complex RPA, which promotes ATR activation through recruitment of ATRIP, a critical ATR regulator. The Rad17/RFC complex also binds to RPA-coated ssDNA and loads the 9-1-1 complex (Rad9-Hus1-Rad1). 9-1-1 recruits TOPBP1, which is necessary for ATR activation. Claspin mediates the activation of Chk1 by ATR, leading to the replication stress response. T bars indicates inhibition. Arrows indicate activation.

\subsection{ATM Signaling and Productive Viral Replication}

In response to DSBs, ATM is conically activated by the MRN (Mre11, Rad50, Nbs1) complex, which serves as a sensor of DNA damage, and by acetylation via the TIP60 acetyltransferase [122,124-126] (Figure 4). ATM then phosphorylates numerous downstream targets, including the histone variant H2A.X (histone 2A variant $X$ ), which initiates repair factor recruitment to sites of DNA damage in a highly ordered fashion [127]. ATM elicits its effects on cell cycle arrest and DNA repair through the activation of numerous kinases, including Chk2 and p38MAPK [122,128] (Figure 4). Chk2 phosphorylates many downstream effectors, including repair factors such as BRCA1 (Breast Cancer Gene 1), p53, and the Cdc25c family of phosphatases to mediate G2/M arrest [129]. p38MAPK (Mitogen Activated Protein Kinase) signaling is independent of Chk2 and induces the DDR through phosphorylation of MK2 (MAPK-activated protein kinase 2), which in turn phosphorylates downstream substrates to induce G2/M arrest [128]. The ATM effector SMC1 constitutes a third arm of the DDR, which along with Nbs1 induces cell cycle arrest and DNA repair [130,131] (Figure 4). A seminal study by the Laimins lab demonstrated that ATM is constitutively active in high-risk 
HPV31 positive cells [100], and is characterized by the phosphorylation of multiple downstream targets, including H2A.X, Chk2, Nbs1, BRCA1, SMC1, p38MAPK and MK2 [100,132,133] (Figure 5). Subsequent studies demonstrated similar findings for HPV16 and HPV18 [104,134]. Inactivation of the MRN complex in HPV31 positive cells does not abrogate ATM activation [135], suggesting that HPV utilizes a non-canonical mechanism to induce the ATM DDR necessary for productive viral replication. Intriguingly, activation of the ATM pathway is specifically required for productive replication of HPV31 upon differentiation, with inhibition of ATM activity having no effect on episomal maintenance in undifferentiated cells [100]. Similar results were observed for the ATM effector Chk2 [100]. In addition to inactivation of Cdc25c, Chk2 activity is also necessary in differentiating HPV31 positive keratinocytes for activation of caspase-3/7, which is required for cleavage of the E1 viral helicase and viral genome amplification [100,136]. Interestingly, in contrast to Chk2, activation of the p38/MK2 axis of the ATM DDR is induced only upon differentiation [132]. The p38/MK2 complex is also necessary for productive replication of HPV31, though the downstream targets of this complex that drive viral DNA synthesis have not been defined [132].

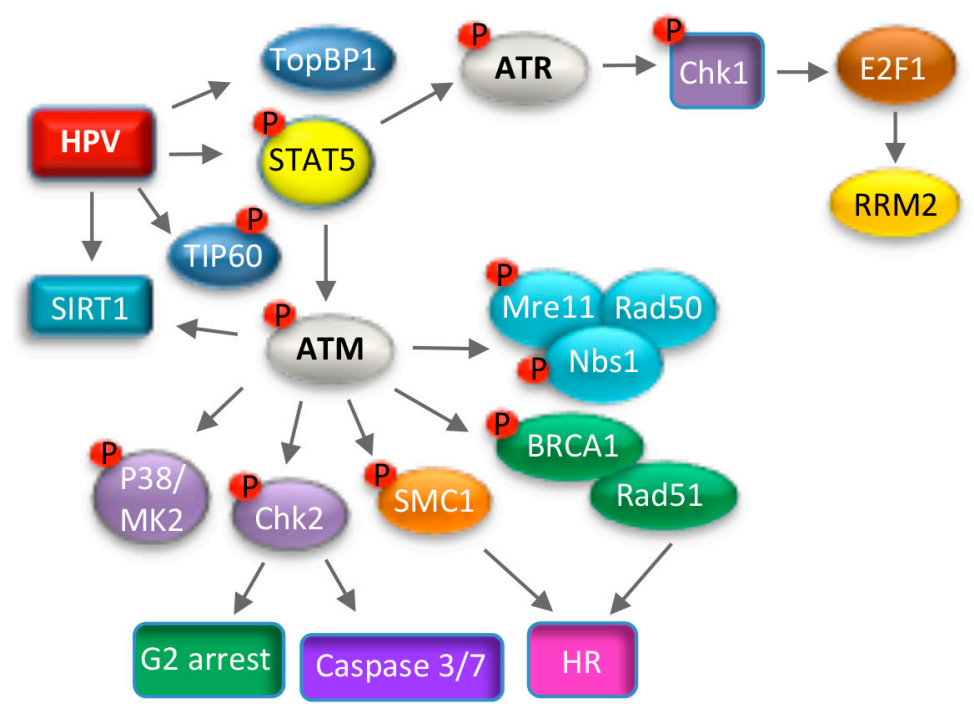

Figure 5. Modulation of the ATM and ATR DNA damage response pathways to promote productive viral replication. HPV-induced activation of ATM requires the STAT5 immune regulator, as well as TIP60, but not the MRN complex. Downstream effectors of ATM required for productive viral replication include the MRN complex, p38/MK2, Chk2, as well as factors involved in homologous recombination repair (Rad51, BRCA1, SMC1). HPV may utilize ATM activity to promote G2 arrest upon differentiation through activities of $\mathrm{Chk2}$, as well as to direct repair to HR on viral genomes through epigenetic modifications and the recruitment of homologous recombination (HR) repair factors. ATR activation in HPV positive cells likely occurs through E7-induced replication stress and requires a STAT5-directed increase in TOPBP1. ATR/Chk1 activation leads to increased levels of E2F1, which drives expression of RRM2, resulting in increased dNTP pools to facilitate productive viral replication.

Multiple ATM signaling components are recruited to productively replicating viral genomes, including ATM, $\gamma$ H2A.X, Chk2, 53BP1, MRN, Rad51 and BRCA1, suggesting a direct role for DNA repair mechanisms in viral DNA synthesis [135,137-139]. Indeed, along with ATM, several of these factors, including the MRN complex, Rad51 and BRCA1, are necessary for DNA repair through homologous recombination (HR), and importantly, are also required for productive replication of HPV31 [101,122,135]. HR is a relatively error-free process, and HPV may preferentially use this method of repair to maintain the integrity of viral DNA during amplification. Structures consistent with recombination have been observed during productive replication of HPV31 and HPV16 that are not detected during maintenance replication in undifferentiated cells [140]. These observations 
suggest that amplification of viral genomes upon differentiation occurs in a distinct manner that may require ATM-driven HR. Initiation of HR requires resection of DSBs, which requires ATM activity, as well as BRCA1 and the MRN resection complex [121]. Resection is required for loading the Rad51 recombinase onto DNA, which then facilitates strand invasion into homologous sequences [122]. Rad51 binding to HPV31 DNA increases upon differentiation, and inhibition of Rad51's DNA binding ability blocks productive viral replication, suggesting that viral DNA resection is necessary for amplification of viral genomes [101]. In support of this, Anacker et al. demonstrated that the MRN complex is required for Rad51 localization to HPV31 replication foci, and that Mre11's nuclease activity is necessary for productive viral replication [135]. Recent studies have shown that SMC1 is also required for productive replication of HPV31 [133]. SMC1 is a member of the sister chromatid cohesion complex that is important for chromosome segregation during mitosis [141]. The role of SMC1 in productive viral replication is not clear, but SMC1 is recruited to the viral genome in a complex with CTCF insulator proteins [133]. SMC1 is postulated to promote HR by maintaining the close proximity of sister chromatids at DSBs [131], and may serve a similar role on HPV genomes to facilitate recombination-dependent replication.

In the context of the complete HPV31 genome, ATM activation occurs in a manner dependent on E7's Rb binding domain [142]. Expression of HPV18 E7 alone in organotypic raft cultures results in activation of ATM, Chk2 and Chk1 in the suprabasal layers, offering support that E7 contributes to productive viral replication through eliciting ATM activation in differentiating cells [104]. HPV31 E7 regulates the activation of ATM through STAT5, an immune regulator that is required for productive viral replication [143] (Figure 5). How STAT5 leads to ATM activation is currently unclear, but may involve STAT5-dependent activation of TIP60 [144]. In addition to ATM activation, HPV31 E7 contributes to productive viral replication by increasing the protein half-life of several DNA repair factors that are required for productive replication (e.g., ATM, Chk2, Chk1, Mre11, Rad50, Nbs1, Rad51 and BRCA1), ensuring high levels for efficient viral DNA synthesis [142]. Expression of the E1 viral helicase alone from high-risk and low-risk HPV types is sufficient to induce ATM activation, which may occur through the induction of DSBs due to E1's ability to non-specifically bind and unwind cellular DNA $[134,145,146]$. In the presence of E2, E1 is recruited to the viral origin of replication, along with multiple components of the ATM and ATR pathway [134,145,147]. How ATM activity is regulated by E7 versus E1 during the viral life cycle remains to be determined. In addition, whether activation of the ATM DDR occurs in the context of low-risk HPV infection, and if this response is required for productive replication is currently unknown. In contrast to the Alpha high-risk HPV types, beta HPV E6 and E7 proteins reduce expression of ATM and ATR, as well as the HR factors Rad51 and BRCA2, in turn delaying repair foci formation in response to UV exposure [148]. Whether inactivation of the DDR is necessary for the life cycle of beta HPVs is not yet known due to the lack of experimental systems to study replication.

The recruitment of DNA repair factors to sites of DNA damage requires alterations in chromatin structure orchestrated through ATP-dependent remodeling complexes and post-translational modifications of histones (e.g., acetylation, ubiquitylation, phosphorylation, methylation) $[149,150]$. ATM-induced phosphorylation of H2A.X $(\gamma \mathrm{H} 2 \mathrm{~A} . \mathrm{X})$ is one of the key effectors in modulating chromatin dynamics in response to DSBs [127]. $\gamma \mathrm{H} 2 \mathrm{~A}$.X initiates the assembly of repair factors at DNA lesions in a highly regulated manner, including HR factors (MRN, Brca1 and Rad51) [151]. $\gamma \mathrm{H} 2 \mathrm{~A} . \mathrm{X}$ is bound to HPV31 DNA and binding increases during productive viral replication, suggesting that $\gamma \mathrm{H} 2 \mathrm{~A} . \mathrm{X}$ may serve to assemble HR repair factors at viral replication sites [138,152]. The DDR-associated histone deacetylase SIRT1 and the acetyltransferase TIP60 have also been linked to productive viral replication. SIRT1 channels repair to HR by recruiting Nbs1 and Rad51 to damaged DNA in an ATMand $\gamma \mathrm{H} 2 \mathrm{AX}$-dependent manner [153]. Interestingly, SIRT1 binds to HPV31 DNA and is necessary for productive viral replication, which may be mediated through the recruitment of Nbs1 and Rad51 to viral replication foci [139]. TIP60 is upregulated in HPV31 positive keratinocytes and is also necessary for productive viral replication [144]. While this presumably is due to TIP60's role in ATM 
activation, TIP60 can also influence repair to the HR pathway through the acetylation of histone $\mathrm{H} 4$ and attenuation of 53BP1 binding, which promotes repair through NHEJ [154]. SIRT1 and TIP60 may modify viral chromatin to ensure the recruitment of HR factors to productively replicating viral genomes. How the HPV life cycle may be epigenetically regulated through ATM activity is an interesting area of investigation.

\subsection{ATR Signaling and Productive Viral Replication}

Replication stress results in formation of single strand DNA (ssDNA) at stalled replication forks that activates the ATR kinase [155]. ATR and its downstream target Chk1 protect stalled replication forks and prevent excessive origin firing, maintaining genome integrity. High-risk HPV positive cells exhibit constitutive activation of the ATR pathway, indicating that replication stress is a chronic problem that HPV has to contend with $[100,110,111]$. Unscheduled cell cycle entry induced by high-risk HPV E6 and E7 proteins results in replication stress due to a disconnect between activation of cellular DNA synthesis and the availability of supplies required for replication $[156,157]$. This is thought to occur through E7's ability to target Rb for degradation. In support of this, mutation of E7's Rb binding domain in the context of the HPV31 genome prevents ATR signaling [142]. ATR activation requires recruitment to RPA-coated ssDNA by its regulator ATRIP [158] (Figure 4). ssDNA-RPA also recruits the RFC/Rad17 complex, which facilitates loading of the 9-1-1 complex at stalled replication forks [159]. The 9-1-1 complex then recruits TOPBP1 to activate ATR's kinase activity [160]. Intriguingly, HPV31 E7 ensures that infected cells can sufficiently respond to replication stress through ATR activation by increasing the levels of TOPBP1 in a STAT5-dependent manner [110] (Figure 5). Although E1 of high-risk and low-risk types can also independently activate ATR, it is unclear if this results from non-specific binding and unwinding of cellular DNA, or if increased E1 activity on viral DNA during productive viral replication results in in replication stress [134,145].

Inhibition of ATR, as well as its downstream target Chk1, blocks productive replication of HPV31, and also decreases HPV31 and HPV16 copy number in undifferentiated cells $[110,111,161]$. In response to replication stress, ATR phosphorylates RPA on Ser33 [162]. pRPA Ser33 localizes to HPV31 replication foci, suggesting that viral genomes are subject to replication stress during productive replication [138]. Activation of the ATR/Chk1 pathway may be important in repairing stalled forks that occur during amplification of viral genomes. Upon replication stress, activation of the ATR/Chk1 pathway is instrumental in maintaining E2F signaling, ensuring the expression of cellular genes that facilitate DNA repair and cell survival [163]. This is particularly important in cancer cells, which typically exhibit high levels of replication stress [164-166]. Recent studies from our lab demonstrated that HPV31 utilizes the ATR/Chk1/E2F1 arm of the DDR to increase levels of RRM2, the small subunit of the ribonucleotide reductase complex, in an E7-dependent manner [111] (Figure 5). RRM2, along with the large subunit RRM1, is necessary for the conversion of ribonucleotides to deoxyribonucleotides, providing dNTPs for replication, DNA repair and survival [167]. Knockdown of RRM2 reduced dNTP pools in differentiating HPV31 positive cells and blocked productive replication [111]. These studies indicate E7 induced cell-cycle re-entry upon differentiation results in replication stress that activates the ATR/Chk1 pathway to maintain E2F signaling. Importantly, these studies demonstrate that HPV exploits the ATR DNA damage response to ensure an adequate supply of dNTPs for productive replication, providing a replication competent environment in cells that are no longer dividing. Understanding the full extent of the ATR pathway throughout the viral life cycle is an important area of future investigation.

\subsection{Consequences of Utilizing the DNA Damage Response for Replication}

Studies have shown that HPV replication foci tend to form near common fragile sites, which are regions of the cellular genome that are prone to replication stress and recruit DNA repair factors to maintain genomic stability $[168,169]$. HPV may preferentially replicate adjacent to fragile sites to readily have access to DNA repair factors to facilitate recombination-directed replication. Interestingly, 
in cancers associated with oncogenic HPV types, viral DNA is often found integrated into host DNA at common fragile sites [170-173]. Integration is a dead-end for virus production and almost always results in increased expression of the E6 and E7 oncogenes [174]. Deregulated E6/E7 expression leads to a proliferative advantage and the clonal outgrowth of cells containing integrated viral DNA. While replicating near areas of cellular replication stress may be beneficial to viral persistence and productive viral replication, the close association of HPV replication foci with areas of the cellular DNA damage may increase the chance of accidental integration of the viral genome, and may explain the tendency for HPV to integrate into common fragile sites of host DNA [175]. Furthermore, recent studies from the Galloway lab demonstrated that high-risk E6 and E7 proteins attenuate the repair of cellular DSBs through the HR pathway. While this likely ensures HR factors are available for viral replication, the presence of persistent, unrepaired DNA breaks increases the opportunity for viral genome integration [176]. These integration events, in turn, may contribute to HPV oncogenesis through E6/E7-mediated genomic instability.

\section{Conclusions}

In order to provide a replication-competent environment, HPVs co-opt particular host cell pathways and interactions that regulate epithelial differentiation and cellular proliferation, as well facilitate repair of damaged DNA. Temporal regulation of viral gene expression is necessary to restrict high levels of viral gene expression, replication and virion production to the uppermost layers of the epithelium, protecting HPV-infected cells from detection by the immune response. This is achieved through differential usage of promoters and polyadenylation sites, as well as alternative splicing. In addition, E6 and E7 play critical roles in modulating innate immune responses to facilitate viral persistence and promote viral replication [27]. Cooperation between the activities of E6, E7, E1, E2, E4 and E5 upon differentiation allows HPV to establish an environment supportive of productive replication in non-dividing cells. Our understanding of how HPVs regulate the productive phase of the viral life cycle has increased dramatically over the past several years, particularly regarding how high-risk HPVs activate and utilize DNA repair pathways to amplify viral genomes. However, much remains to be learned regarding how alpha HPVs manipulate cellular pathways to facilitate viral replication, and in turn, how hijacking these pathways may affect the integrity of the cellular genome. Further understanding of the mechanisms by which HPV establishes a replication-competent environment throughout the viral life cycle is important to identify novel cellular targets that could be exploited therapeutically for the treatment of HPV-associated diseases.

Acknowledgments: This work was supported by the National Institutes of Health (1R01CA181581; to Cary A. Moody) and the American Cancer Society (A14-0113; to Cary A. Moody).

Conflicts of Interest: The authors declare no conflict of interest.

\section{References}

1. Van Doorslaer, K.; Tan, Q.; Xirasagar, S.; Bandaru, S.; Gopalan, V.; Mohamoud, Y.; Huyen, Y.; McBride, A.A. The papillomavirus episteme: A central resource for papillomavirus sequence data and analysis. Nucleic Acids Res. 2013, 41, 571-578. [CrossRef] [PubMed]

2. Bernard, H.U.; Burk, R.D.; Chen, Z.; van Doorslaer, K.; zur Hausen, H.; de Villiers, E.M. Classification of papillomaviruses (PVS) based on 189 PV types and proposal of taxonomic amendments. Virology 2010, 401, 70-79. [CrossRef] [PubMed]

3. Walboomers, J.M.; Jacobs, M.V.; Manos, M.M.; Bosch, F.X.; Kummer, J.A.; Shah, K.V.; Snijders, P.J.; Peto, J.; Meijer, C.J.; Munoz, N. Human papillomavirus is a necessary cause of invasive cervical cancer worldwide. J. Pathol. 1999, 189, 12-19. [CrossRef]

4. Stanley, M. Pathology and epidemiology of HPV infection in females. Gynecol. Oncol. 2010, 117, S5-S10. [CrossRef] [PubMed]

5. Gillison, M.L.; Chaturvedi, A.K.; Anderson, W.F.; Fakhry, C. Epidemiology of human papillomavirus-positive head and neck squamous cell carcinoma. J. Clin. Oncol. 2015, 33, 3235-3242. [CrossRef] [PubMed] 
6. Tommasino, M. The biology of $\beta$ human papillomaviruses. Virus Res. 2017, 231, 128-138. [CrossRef] [PubMed]

7. Howley, P.M.; Pfister, H.J. $\beta$ genus papillomaviruses and skin cancer. Virology 2015, 479-480, $290-296$. [CrossRef] [PubMed]

8. Egawa, N.; Egawa, K.; Griffin, H.; Doorbar, J. Human papillomaviruses; epithelial tropisms, and the development of neoplasia. Viruses 2015, 7, 3863-3890. [CrossRef] [PubMed]

9. McBride, A.A. Mechanisms and strategies of papillomavirus replication. Biol. Chem. 2017, 398, 919-927. [CrossRef] [PubMed]

10. Longworth, M.S.; Laimins, L.A. Pathogenesis of human papillomaviruses in differentiating epithelia. Microbiol. Mol. Biol. Rev. 2004, 68, 362-372. [CrossRef] [PubMed]

11. Pyeon, D.; Pearce, S.M.; Lank, S.M.; Ahlquist, P.; Lambert, P.F. Establishment of human papillomavirus infection requires cell cycle progression. PLoS Pathog. 2009, 5, e1000318. [CrossRef] [PubMed]

12. Maglennon, G.A.; McIntosh, P.; Doorbar, J. Persistence of viral DNA in the epithelial basal layer suggests a model for papillomavirus latency following immune regression. Virology 2011, 414, 153-163. [CrossRef] [PubMed]

13. Koster, M.I.; Roop, D.R. Mechanisms regulating epithelial stratification. Annu. Rev. Cell Dev. Biol. 2007, 23, 93-113. [CrossRef] [PubMed]

14. Favre, M.; Breitburd, F.; Croissant, O.; Orth, G. Chromatin-like structures obtained after alkaline disruption of bovine and human papillomaviruses. J. Virol. 1977, 21, 1205-1209. [PubMed]

15. Stunkel, W.; Bernard, H.U. The chromatin structure of the long control region of human papillomavirus type 16 represses viral oncoprotein expression. J. Virol. 1999, 73, 1918-1930. [PubMed]

16. Graham, S.V.; Faizo, A.A. Control of human papillomavirus gene expression by alternative splicing. Virus Res. 2017, 231, 83-95. [CrossRef] [PubMed]

17. Van Doorslaer, K.; Li, Z.; Xirasagar, S.; Maes, P.; Kaminsky, D.; Liou, D.; Sun, Q.; Kaur, R.; Huyen, Y.; McBride, A.A. The papillomavirus episteme: A major update to the papillomavirus sequence database. Nucleic Acids Res. 2017, 45, D499-D506. [CrossRef] [PubMed]

18. Geisen, C.; Kahn, T. Promoter activity of sequences located upstream of the human papillomavirus types of 16 and 18 late regions. J. Gen. Virol. 1996, 77, 2193-2200. [CrossRef] [PubMed]

19. Ozbun, M.A.; Meyers, C. Temporal usage of multiple promoters during the life cycle of human papillomavirus type 31b. J. Virol. 1998, 72, 2715-2722. [PubMed]

20. Braunstein, T.H.; Madsen, B.S.; Gavnholt, B.; Rosenstierne, M.W.; Johnsen, C.K.; Norrild, B. Identification of a new promoter in the early region of the human papillomavirus type 16 genome. J. Gen. Virol. 1999, 80, 3241-3250. [CrossRef] [PubMed]

21. Bergvall, M.; Melendy, T.; Archambault, J. The E1 proteins. Virology 2013, 445, 35-56. [CrossRef] [PubMed]

22. McBride, A.A. The papillomavirus E2 proteins. Virology 2013, 445, 57-79. [CrossRef] [PubMed]

23. Roman, A.; Munger, K. The papillomavirus E7 proteins. Virology 2013, 445, 138-168. [CrossRef] [PubMed]

24. Vande Pol, S.B.; Klingelhutz, A.J. Papillomavirus E6 oncoproteins. Virology 2013, 445, 115-137. [CrossRef] [PubMed]

25. Anacker, D.C.; Moody, C.A. Modulation of the DNA damage response during the life cycle of human papillomaviruses. Virus Res. 2017, 231, 41-49. [CrossRef] [PubMed]

26. Moody, C.A.; Laimins, L.A. Human papillomavirus oncoproteins: Pathways to transformation. Nat. Rev. Cancer 2010, 10, 550-560. [CrossRef] [PubMed]

27. Hong, S.; Laimins, L.A. Manipulation of the innate immune response by human papillomaviruses. Virus Res. 2017, 231, 34-40. [CrossRef] [PubMed]

28. Doorbar, J. The E4 protein; structure, function and patterns of expression. Virology 2013, 445, 80-98. [CrossRef] [PubMed]

29. Egawa, N.; Wang, Q.; Griffin, H.M.; Murakami, I.; Jackson, D.; Mahmood, R.; Doorbar, J. HPV16 and 18 genome amplification show different e4-dependence, with 16E4 enhancing E1 nuclear accumulation and replicative efficiency via its cell cycle arrest and kinase activation functions. PLoS Pathog. 2017, 13, e1006282. [CrossRef] [PubMed]

30. Fang, L.; Budgeon, L.R.; Doorbar, J.; Briggs, E.R.; Howett, M.K. The human papillomavirus type 11 E1^E4 protein is not essential for viral genome amplification. Virology 2006, 351, 271-279. [CrossRef] [PubMed]

31. Wilson, R.; Fehrmann, F.; Laimins, L.A. Role of the E1^Е4 protein in the differentiation-dependent life cycle of human papillomavirus type 31. J. Virol. 2005, 79, 6732-6740. [CrossRef] [PubMed] 
32. Wilson, R.; Ryan, G.B.; Knight, G.L.; Laimins, L.A.; Roberts, S. The full-length E1E4 protein of human papillomavirus type 18 modulates differentiation-dependent viral DNA amplification and late gene expression. Virology 2007, 362, 453-460. [CrossRef] [PubMed]

33. Fehrmann, F.; Klumpp, D.J.; Laimins, L.A. Human papillomavirus type 31 E5 protein supports cell cycle progression and activates late viral functions upon epithelial differentiation. J. Virol. 2003, 77, 2819-2831. [CrossRef] [PubMed]

34. Dreer, M.; van de Poel, S.; Stubenrauch, F. Control of viral replication and transcription by the papillomavirus E8^E2 protein. Virus Res. 2017, 231, 96-102. [CrossRef] [PubMed]

35. Grassmann, K.; Rapp, B.; Maschek, H.; Petry, K.U.; Iftner, T. Identification of a differentiation-inducible promoter in the E7 open reading frame of human papillomavirus type 16 (HPV-16) in raft cultures of a new cell line containing high copy numbers of episomal HPV-16 DNA. J. Virol. 1996, 70, 2339-2349. [PubMed]

36. Hummel, M.; Hudson, J.B.; Laimins, L.A. Differentiation-induced and constitutive transcription of human papillomavirus type 31B in cell lines containing viral episomes. J. Virol. 1992, 66, 6070-6080. [PubMed]

37. Klumpp, D.J.; Laimins, L.A. Differentiation-induced changes in promoter usage for transcripts encoding the human papillomavirus type 31 replication protein E1. Virology 1999, 257, 239-246. [CrossRef] [PubMed]

38. Wooldridge, T.R.; Laimins, L.A. Regulation of human papillomavirus type 31 gene expression during the differentiation-dependent life cycle through histone modifications and transcription factor binding. Virology 2008, 374, 371-380. [CrossRef] [PubMed]

39. Del Mar Pena, L.M.; Laimins, L.A. Differentiation-dependent chromatin rearrangement coincides with activation of human papillomavirus type 31 late gene expression. J. Virol. 2001, 75, 10005-10013. [CrossRef] [PubMed]

40. Carson, A.; Khan, S.A. Characterization of transcription factor binding to human papillomavirus type 16 DNA during cellular differentiation. J. Virol. 2006, 80, 4356-4362. [CrossRef] [PubMed]

41. Gunasekharan, V.; Hache, G.; Laimins, L. Differentiation-dependent changes in levels of C/EBP $\beta$ repressors and activators regulate human papillomavirus type 31 late gene expression. J. Virol. 2012, 86, 5393-5398. [CrossRef] [PubMed]

42. Songock, W.K.; Scott, M.L.; Bodily, J.M. Regulation of the human papillomavirus type 16 late promoter by transcriptional elongation. Virology 2017, 507, 179-191. [CrossRef] [PubMed]

43. Johansson, C.; Somberg, M.; Li, X.; Backstrom Winquist, E.; Fay, J.; Ryan, F.; Pim, D.; Banks, L.; Schwartz, S. HPV-16 E2 contributes to induction of HPV-16 late gene expression by inhibiting early polyadenylation. EMBO J. 2012, 31, 3212-3227. [CrossRef] [PubMed]

44. Maitland, N.J.; Conway, S.; Wilkinson, N.S.; Ramsdale, J.; Morris, J.R.; Sanders, C.M.; Burns, J.E.; Stern, P.L.; Wells, M. Expression patterns of the human papillomavirus type 16 transcription factor E2 in low- and high-grade cervical intraepithelial neoplasia. J. Pathol. 1998, 186, 275-280. [CrossRef]

45. Xue, Y.; Bellanger, S.; Zhang, W.; Lim, D.; Low, J.; Lunny, D.; Thierry, F. HPV16 E2 is an immediate early marker of viral infection, preceding E7 expression in precursor structures of cervical carcinoma. Cancer Res. 2010, 70, 5316-5325. [CrossRef] [PubMed]

46. Graham, S.V. Keratinocyte differentiation-dependent human papillomavirus gene regulation. Viruses 2017, 9, E245. [CrossRef] [PubMed]

47. Bentley, D.L. Coupling mRNA processing with transcription in time and space. Nat. Rev. Genet. 2014, 15, 163-175. [CrossRef] [PubMed]

48. Klymenko, T.; Hernandez-Lopez, H.; MacDonald, A.I.; Bodily, J.M.; Graham, S.V. Human papillomavirus E2 regulates SRSF3 (SRP20) to promote capsid protein expression in infected differentiated keratinocytes. J. Virol. 2016, 90, 5047-5058. [CrossRef] [PubMed]

49. Somberg, M.; Li, X.; Johansson, C.; Orru, B.; Chang, R.; Rush, M.; Fay, J.; Ryan, F.; Schwartz, S. Serine/arginine-rich protein 30c activates human papillomavirus type $16 \mathrm{~L} 1 \mathrm{mRNA}$ expression via a bimodal mechanism. J. Gen. Virol. 2011, 92, 2411-2421. [CrossRef] [PubMed]

50. Paris, C.; Pentland, I.; Groves, I.; Roberts, D.C.; Powis, S.J.; Coleman, N.; Roberts, S.; Parish, J.L. CCCTC-binding factor recruitment to the early region of the human papillomavirus 18 genome regulates viral oncogene expression. J. Virol. 2015, 89, 4770-4785. [CrossRef] [PubMed]

51. Dyson, N.; Howley, P.M.; Munger, K.; Harlow, E. The human papilloma virus-16 E7 oncoprotein is able to bind to the retinoblastoma gene product. Science 1989, 243, 934-937. [CrossRef] [PubMed]

52. Dyson, N. The regulation of E2F by pRB-family proteins. Genes Dev. 1998, 12, 2245-2262. [CrossRef] [PubMed] 
53. Munger, K.; Werness, B.A.; Dyson, N.; Phelps, W.C.; Harlow, E.; Howley, P.M. Complex formation of human papillomavirus E7 proteins with the retinoblastoma tumor suppressor gene product. EMBO J. 1989, 8, 4099-4105. [PubMed]

54. Chellappan, S.; Kraus, V.B.; Kroger, B.; Munger, K.; Howley, P.M.; Phelps, W.C.; Nevins, J.R. Adenovirus E1A, simian virus 40 tumor antigen, and human papillomavirus E7 protein share the capacity to disrupt the interaction between transcription factor E2F and the retinoblastoma gene product. Proc. Natl. Acad. Sci. USA 1992, 89, 4549-4553. [CrossRef] [PubMed]

55. Cheng, S.; Schmidt-Grimminger, D.C.; Murant, T.; Broker, T.R.; Chow, L.T. Differentiation-dependent up-regulation of the human papillomavirus E7 gene reactivates cellular DNA replication in suprabasal differentiated keratinocytes. Genes Dev. 1995, 9, 2335-2349. [CrossRef] [PubMed]

56. Chen, H.Z.; Tsai, S.Y.; Leone, G. Emerging roles of E2Fs in cancer: An exit from cell cycle control. Nat. Rev. Cancer 2009, 9, 785-797. [CrossRef] [PubMed]

57. Jones, D.L.; Alani, R.M.; Munger, K. The human papillomavirus E7 oncoprotein can uncouple cellular differentiation and proliferation in human keratinocytes by abrogating p21CIP1-mediated inhibition of CDK2. Genes Dev. 1997, 11, 2101-2111. [CrossRef] [PubMed]

58. Demers, G.W.; Espling, E.; Harry, J.B.; Etscheid, B.G.; Galloway, D.A. Abrogation of growth arrest signals by human papillomavirus type $16 \mathrm{E} 7$ is mediated by sequences required for transformation. J. Virol. 1996, 70, 6862-6869. [PubMed]

59. Demeter, L.M.; Stoler, M.H.; Broker, T.R.; Chow, L.T. Induction of proliferating cell nuclear antigen in differentiated keratinocytes of human papillomavirus-infected lesions. Hum. Pathol. 1994, 25, 343-348. [CrossRef]

60. Barrow-Laing, L.; Chen, W.; Roman, A. Low- and high-risk human papillomavirus E7 proteins regulate p130 differently. Virology 2010, 400, 233-239. [CrossRef] [PubMed]

61. Zhang, B.; Chen, W.; Roman, A. The E7 proteins of low- and high-risk human papillomaviruses share the ability to target the pRB family member p130 for degradation. Proc. Natl. Acad. Sci. USA 2006, 103, 437-442. [CrossRef] [PubMed]

62. Wilson, R.; Laimins, L.A. Differentiation of HPV-containing cells using organotypic "raft" culture or methylcellulose. Methods Mol. Med. 2005, 119, 157-169. [PubMed]

63. Flores, E.R.; Allen-Hoffmann, B.L.; Lee, D.; Lambert, P.F. The human papillomavirus type 16 E7 oncogene is required for the productive stage of the viral life cycle. J. Virol. 2000, 74, 6622-6631. [CrossRef] [PubMed]

64. Longworth, M.S.; Laimins, L.A. The binding of histone deacetylases and the integrity of zinc finger-like motifs of the E7 protein are essential for the life cycle of human papillomavirus type 31. J. Virol. 2004, 78, 3533-3541. [CrossRef] [PubMed]

65. Longworth, M.S.; Wilson, R.; Laimins, L.A. HPV31 E7 facilitates replication by activating E2F2 transcription through its interaction with HDACs. EMBO J. 2005, 24, 1821-1830. [CrossRef] [PubMed]

66. Brehm, A.; Nielsen, S.J.; Miska, E.A.; McCance, D.J.; Reid, J.L.; Bannister, A.J.; Kouzarides, T. The E7 oncoprotein associates with MI2 and histone deacetylase activity to promote cell growth. EMBO J. 1999, 18, 2449-2458. [CrossRef] [PubMed]

67. Missero, C.; Calautti, E.; Eckner, R.; Chin, J.; Tsai, L.H.; Livingston, D.M.; Dotto, G.P. Involvement of the cell-cycle inhibitor CIP1/WAF1 and the E1A-associated p300 protein in terminal differentiation. Proc. Natl. Acad. Sci. USA 1995, 92, 5451-5455. [CrossRef] [PubMed]

68. Deshpande, A.; Sicinski, P.; Hinds, P.W. Cyclins and CDKs in development and cancer: A perspective. Oncogene 2005, 24, 2909-2915. [CrossRef] [PubMed]

69. Funk, J.O.; Waga, S.; Harry, J.B.; Espling, E.; Stillman, B.; Galloway, D.A. Inhibition of CDK activity and pCNA-dependent DNA replication by p21 is blocked by interaction with the HPV-16 E7 oncoprotein. Genes Dev. 1997, 11, 2090-2100. [CrossRef] [PubMed]

70. Nguyen, C.L.; Munger, K. Direct association of the HPV16 E7 oncoprotein with cyclin A/CDK2 and cyclin E/CDK2 complexes. Virology 2008, 380, 21-25. [CrossRef] [PubMed]

71. Katich, S.C.; Zerfass-Thome, K.; Hoffmann, I. Regulation of the CDC25A gene by the human papillomavirus type 16 E7 oncogene. Oncogene 2001, 20, 543-550. [CrossRef] [PubMed]

72. Nguyen, D.X.; Westbrook, T.F.; McCance, D.J. Human papillomavirus type 16 E7 maintains elevated levels of the CDC25A tyrosine phosphatase during deregulation of cell cycle arrest. J. Virol. 2002, 76, 619-632. [CrossRef] [PubMed] 
73. Deng, W.; Lin, B.Y.; Jin, G.; Wheeler, C.G.; Ma, T.; Harper, J.W.; Broker, T.R.; Chow, L.T. Cyclin/CDK regulates the nucleocytoplasmic localization of the human papillomavirus E1 DNA helicase. J. Virol. 2004, 78, 13954-13965. [CrossRef] [PubMed]

74. Fradet-Turcotte, A.; Moody, C.; Laimins, L.A.; Archambault, J. Nuclear export of human papillomavirus type $31 \mathrm{E} 1$ is regulated by CDK2 phosphorylation and required for viral genome maintenance. J. Virol. 2010, 84, 11747-11760. [CrossRef] [PubMed]

75. Genther, S.M.; Sterling, S.; Duensing, S.; Munger, K.; Sattler, C.; Lambert, P.F. Quantitative role of the human papillomavirus type 16 E5 gene during the productive stage of the viral life cycle. J. Virol. 2003, 77, 2832-2842. [CrossRef] [PubMed]

76. Regan, J.A.; Laimins, L.A. Bap31 is a novel target of the human papillomavirus E5 protein. J. Virol. 2008, 82, 10042-10051. [CrossRef] [PubMed]

77. DiMaio, D.; Petti, L.M. The E5 proteins. Virology 2013, 445, 99-114. [CrossRef] [PubMed]

78. Huibregtse, J.M.; Scheffner, M.; Howley, P.M. A cellular protein mediates association of p53 with the E6 oncoprotein of human papillomavirus types 16 or 18. EMBO J. 1991, 10, 4129-4135. [PubMed]

79. Scheffner, M.; Werness, B.A.; Huibregtse, J.M.; Levine, A.J.; Howley, P.M. The E6 oncoprotein encoded by human papillomavirus types 16 and 18 promotes the degradation of p53. Cell 1990, 63, 1129-1136. [CrossRef]

80. Scheffner, M.; Huibregtse, J.M.; Vierstra, R.D.; Howley, P.M. The HPV-16 E6 and E6-AP complex functions as a ubiquitin-protein ligase in the ubiquitination of p53. Cell 1993, 75, 495-505. [CrossRef]

81. Kho, E.Y.; Wang, H.K.; Banerjee, N.S.; Broker, T.R.; Chow, L.T. HPV-18 E6 mutants reveal p53 modulation of viral DNA amplification in organotypic cultures. Proc. Natl. Acad. Sci. USA 2013, 110, 7542-7549. [CrossRef] [PubMed]

82. Massimi, P.; Pim, D.; Bertoli, C.; Bouvard, V.; Banks, L. Interaction between the HPV-16 E2 transcriptional activator and p53. Oncogene 1999, 18, 7748-7754. [CrossRef] [PubMed]

83. Brown, C.; Kowalczyk, A.M.; Taylor, E.R.; Morgan, I.M.; Gaston, K. p53 represses human papillomavirus type 16 DNA replication via the viral E2 protein. Virol. J. 2008, 5, 5. [CrossRef] [PubMed]

84. Ganti, K.; Broniarczyk, J.; Manoubi, W.; Massimi, P.; Mittal, S.; Pim, D.; Szalmas, A.; Thatte, J.; Thomas, M.; Tomaic, V.; et al. The human papillomavirus E6 PDZ binding motif: From life cycle to malignancy. Viruses 2015, 7, 3530-3551. [CrossRef] [PubMed]

85. Lee, S.S.; Weiss, R.S.; Javier, R.T. Binding of human virus oncoproteins to HDLG/Sap97, a mammalian homolog of the drosophila discs large tumor suppressor protein. Proc. Natl. Acad. Sci. USA 1997, 94, 6670-6675. [CrossRef] [PubMed]

86. Kiyono, T.; Hiraiwa, A.; Fujita, M.; Hayashi, Y.; Akiyama, T.; Ishibashi, M. Binding of high-risk human papillomavirus E6 oncoproteins to the human homologue of the drosophila discs large tumor suppressor protein. Proc. Natl. Acad. Sci. USA 1997, 94, 11612-11616. [CrossRef] [PubMed]

87. Delury, C.P.; Marsh, E.K.; James, C.D.; Boon, S.S.; Banks, L.; Knight, G.L.; Roberts, S. The role of protein kinase a regulation of the E6 PDZ-binding domain during the differentiation-dependent life cycle of human papillomavirus type 18. J. Virol. 2013, 87, 9463-9472. [CrossRef] [PubMed]

88. Lee, C.; Laimins, L.A. Role of the PDZ domain-binding motif of the oncoprotein E6 in the pathogenesis of human papillomavirus type 31. J. Virol. 2004, 78, 12366-12377. [CrossRef] [PubMed]

89. Nicolaides, L.; Davy, C.; Raj, K.; Kranjec, C.; Banks, L.; Doorbar, J. Stabilization of HPV16 E6 protein by PDZ proteins, and potential implications for genome maintenance. Virology 2011, 414, 137-145. [CrossRef] [PubMed]

90. Marsh, E.K.; Delury, C.P.; Davies, N.J.; Weston, C.J.; Miah, M.A.L.; Banks, L.; Parish, J.L.; Higgs, M.R.; Roberts, S. Mitotic control of human papillomavirus genome-containing cells is regulated by the function of the PDZ-binding motif of the E6 oncoprotein. Oncotarget 2017, 8, 19491-19506. [CrossRef] [PubMed]

91. Cai, X.; Li, G.; Laimins, L.A.; Cullen, B.R. Human papillomavirus genotype 31 does not express detectable microRNA levels during latent or productive virus replication. J. Virol. 2006, 80, 10890-10893. [CrossRef] [PubMed]

92. Yi, R.; Poy, M.N.; Stoffel, M.; Fuchs, E. A skin microrna promotes differentiation by repressing 'stemness'. Nature 2008, 452, 225-229. [CrossRef] [PubMed]

93. Melino, G.; Memmi, E.M.; Pelicci, P.G.; Bernassola, F. Maintaining epithelial stemness with p63. Sci. Signal. 2015, 8, 9. [CrossRef] [PubMed] 
94. Mighty, K.K.; Laimins, L.A. P63 is necessary for the activation of human papillomavirus late viral functions upon epithelial differentiation. J. Virol. 2011, 85, 8863-8869. [CrossRef] [PubMed]

95. Melar-New, M.; Laimins, L.A. Human papillomaviruses modulate expression of microRNA 203 upon epithelial differentiation to control levels of p63 proteins. J. Virol. 2010, 84, 5212-5221. [CrossRef] [PubMed]

96. Gunasekharan, V.; Laimins, L.A. Human papillomaviruses modulate microrna 145 expression to directly control genome amplification. J. Virol. 2013, 87, 6037-6043. [CrossRef] [PubMed]

97. Sen, G.L.; Boxer, L.D.; Webster, D.E.; Bussat, R.T.; Qu, K.; Zarnegar, B.J.; Johnston, D.; Siprashvili, Z.; Khavari, P.A. Znf750 is a p63 target gene that induces KLF4 to drive terminal epidermal differentiation. Dev. Cell. 2012, 22, 669-677. [CrossRef] [PubMed]

98. Ghaleb, A.M.; Yang, V.W. Kruppel-like factor 4 (KLF4): What we currently know. Gene 2017, 611, $27-37$. [CrossRef] [PubMed]

99. Gunasekharan, V.K.; Li, Y.; Andrade, J.; Laimins, L.A. Post-transcriptional regulation of KLF4 by high-risk human papillomaviruses is necessary for the differentiation-dependent viral life cycle. PLoS Pathog. 2016, 12, e1005747. [CrossRef] [PubMed]

100. Moody, C.A.; Laimins, L.A. Human papillomaviruses activate the ATM DNA damage pathway for viral genome amplification upon differentiation. PLoS Pathog. 2009, 5, e1000605. [CrossRef] [PubMed]

101. Chappell, W.H.; Gautam, D.; Ok, S.T.; Johnson, B.A.; Anacker, D.C.; Moody, C.A. Homologous recombination repair factors RAD51 and BRCA1 are necessary for productive replication of human papillomavirus 31. J. Virol. 2015, 90, 2639-2652. [CrossRef] [PubMed]

102. Banerjee, N.S.; Genovese, N.J.; Noya, F.; Chien, W.M.; Broker, T.R.; Chow, L.T. Conditionally activated E7 proteins of high-risk and low-risk human papillomaviruses induce $S$ phase in postmitotic, differentiated human keratinocytes. J. Virol. 2006, 80, 6517-6524. [CrossRef] [PubMed]

103. Genovese, N.J.; Banerjee, N.S.; Broker, T.R.; Chow, L.T. Casein kinase II motif-dependent phosphorylation of human papillomavirus E7 protein promotes p130 degradation and S-phase induction in differentiated human keratinocytes. J. Virol. 2008, 82, 4862-4873. [CrossRef] [PubMed]

104. Banerjee, N.S.; Wang, H.K.; Broker, T.R.; Chow, L.T. Human papillomavirus (HPV) E7 induces prolonged G2 following S phase reentry in differentiated human keratinocytes. J. Biol. Chem. 2011, 286, 15473-15482. [CrossRef] [PubMed]

105. Wang, H.K.; Duffy, A.A.; Broker, T.R.; Chow, L.T. Robust production and passaging of infectious HPV in squamous epithelium of primary human keratinocytes. Genes Dev. 2009, 23, 181-194. [CrossRef] [PubMed]

106. Nakahara, T.; Peh, W.L.; Doorbar, J.; Lee, D.; Lambert, P.F. Human papillomavirus type 16 e1circumflexe4 contributes to multiple facets of the papillomavirus life cycle. J. Virol. 2005, 79, 13150-13165. [CrossRef] [PubMed]

107. Stark, G.R.; Taylor, W.R. Control of the G2/M transition. Mol. Biotechnol. 2006, 32, 227-248. [CrossRef]

108. Kousholt, A.N.; Menzel, T.; Sorensen, C.S. Pathways for genome integrity in G2 phase of the cell cycle. Biomolecules 2012, 2, 579-607. [CrossRef] [PubMed]

109. Zhou, B.B.; Elledge, S.J. The DNA damage response: Putting checkpoints in perspective. Nature 2000, 408, 433-439. [PubMed]

110. Hong, S.; Cheng, S.; Iovane, A.; Laimins, L.A. STAT- 5 regulates transcription of the topoisomerase II $\beta$-binding protein 1 (TOPBP1) gene to activate the ATR pathway and promote human papillomavirus replication. MBio 2015, 6, e02006-02015. [CrossRef] [PubMed]

111. Anacker, D.C.; Aloor, H.L.; Shepard, C.N.; Lenzi, G.M.; Johnson, B.A.; Kim, B.; Moody, C.A. HPV31 utilizes the ATR-CHK1 pathway to maintain elevated RRM2 levels and a replication-competent environment in differentiating keratinocytes. Virology 2016, 499, 383-396. [CrossRef] [PubMed]

112. Davy, C.E.; Jackson, D.J.; Wang, Q.; Raj, K.; Masterson, P.J.; Fenner, N.F.; Southern, S.; Cuthill, S.; Millar, J.B.; Doorbar, J. Identification of a G(2) arrest domain in the E1 wedge E4 protein of human papillomavirus type 16. J. Virol. 2002, 76, 9806-9818. [CrossRef] [PubMed]

113. Nakahara, T.; Nishimura, A.; Tanaka, M.; Ueno, T.; Ishimoto, A.; Sakai, H. Modulation of the cell division cycle by human papillomavirus type 18 E4. J. Virol. 2002, 76, 10914-10920. [CrossRef] [PubMed]

114. Knight, G.L.; Turnell, A.S.; Roberts, S. Role for wee1 in inhibition of G2-to-M transition through the cooperation of distinct human papillomavirus type $1 \mathrm{E} 4$ proteins. J. Virol. 2006, 80, 7416-7426. [CrossRef] [PubMed] 
115. Davy, C.E.; Jackson, D.J.; Raj, K.; Peh, W.L.; Southern, S.A.; Das, P.; Sorathia, R.; Laskey, P.; Middleton, K.; Nakahara, T.; et al. Human papillomavirus type 16 E1 E4-induced G2 arrest is associated with cytoplasmic retention of active CDK1/cyclin B1 complexes. J. Virol. 2005, 79, 3998-4011. [CrossRef] [PubMed]

116. Wang, Q.; Kennedy, A.; Das, P.; McIntosh, P.B.; Howell, S.A.; Isaacson, E.R.; Hinz, S.A.; Davy, C.; Doorbar, J. Phosphorylation of the human papillomavirus type 16 E1-E4 protein at $\mathrm{t} 57$ by ERK triggers a structural change that enhances keratin binding and protein stability. J. Virol. 2009, 83, 3668-3683. [CrossRef] [PubMed]

117. Yu, J.H.; Lin, B.Y.; Deng, W.; Broker, T.R.; Chow, L.T. Mitogen-activated protein kinases activate the nuclear localization sequence of human papillomavirus type L1 E1 DNA helicase to promote efficient nuclear import. J. Virol. 2007, 81, 5066-5078. [CrossRef] [PubMed]

118. McIntosh, P.B.; Laskey, P.; Sullivan, K.; Davy, C.; Wang, Q.; Jackson, D.J.; Griffin, H.M.; Doorbar, J. E1-E4-mediated keratin phosphorylation and ubiquitylation: A mechanism for keratin depletion in HPV16-infected epithelium. J. Cell. Sci. 2010, 123, 2810-2822. [CrossRef] [PubMed]

119. DeSmet, M.; Kanginakudru, S.; Rietz, A.; Wu, W.H.; Roden, R.; Androphy, E.J. The replicative consequences of papillomavirus E2 protein binding to the origin replication factor ORC2. PLoS Pathog. 2016, 12, e1005934. [CrossRef] [PubMed]

120. Sakakibara, N.; Chen, D.; McBride, A.A. Papillomaviruses use recombination-dependent replication to vegetatively amplify their genomes in differentiated cells. PLoS Pathog. 2013, 9, e1003321. [CrossRef] [PubMed]

121. Ceccaldi, R.; Rondinelli, B.; D'Andrea, A.D. Repair pathway choices and consequences at the double-strand break. Trends Cell Biol. 2016, 26, 52-64. [CrossRef] [PubMed]

122. Ciccia, A.; Elledge, S.J. The DNA damage response: Making it safe to play with knives. Mol. Cell 2010, 40, 179-204. [CrossRef] [PubMed]

123. Cimprich, K.A.; Cortez, D. ATR: An essential regulator of genome integrity. Nat. Rev. Mol. Cell Biol. 2008, 9 , 616-627. [CrossRef] [PubMed]

124. Lee, J.H.; Paull, T.T. ATM activation by DNA double-strand breaks through the MRE11-RAD50-NBS1 complex. Science 2005, 308, 551-554. [CrossRef] [PubMed]

125. Sun, Y.; Jiang, X.; Chen, S.; Fernandes, N.; Price, B.D. A role for the TIP60 histone acetyltransferase in the acetylation and activation of ATM. Proc. Natl. Acad. Sci. USA 2005, 102, 13182-13187. [CrossRef] [PubMed]

126. Williams, R.S.; Williams, J.S.; Tainer, J.A. MRE11-RAD50-NBS1 is a keystone complex connecting DNA repair machinery, double-strand break signaling, and the chromatin template. Biochem. Cell Biol. 2007, 85, 509-520. [CrossRef] [PubMed]

127. Bakkenist, C.J.; Kastan, M.B. Chromatin perturbations during the DNA damage response in higher eukaryotes. DNA Repair (Amst) 2015, 36, 8-12. [CrossRef] [PubMed]

128. Reinhardt, H.C.; Yaffe, M.B. Kinases that control the cell cycle in response to DNA damage: CHK1, CHK2, and MK2. Curr. Opin. Cell Biol. 2009, 21, 245-255. [CrossRef] [PubMed]

129. Donzelli, M.; Draetta, G.F. Regulating mammalian checkpoints through CDC25 inactivation. EMBO Rep. 2003, 4, 671-677. [CrossRef] [PubMed]

130. Yazdi, P.T.; Wang, Y.; Zhao, S.; Patel, N.; Lee, E.Y.; Qin, J. SMC1 is a downstream effector in the ATM/NBS1 branch of the human S-phase checkpoint. Genes Dev. 2002, 16, 571-582. [CrossRef] [PubMed]

131. Lehmann, A.R. The role of SMC proteins in the responses to DNA damage. DNA Repair (Amst) 2005, 4, 309-314. [CrossRef] [PubMed]

132. Satsuka, A.; Mehta, K.; Laimins, L. p38MAPK and MK2 pathways are important for the differentiation-dependent human papillomavirus life cycle. J. Virol. 2015, 89, 1919-1924. [CrossRef] [PubMed]

133. Mehta, K.; Gunasekharan, V.; Satsuka, A.; Laimins, L.A. Human papillomaviruses activate and recruit SMC1 cohesin proteins for the differentiation-dependent life cycle through association with CTCF insulators. PLoS Pathog. 2015, 11, e1004763. [CrossRef] [PubMed]

134. Sakakibara, N.; Mitra, R.; McBride, A.A. The papillomavirus E1 helicase activates a cellular DNA damage response in viral replication foci. J. Virol. 2011, 85, 8981-8995. [CrossRef] [PubMed]

135. Anacker, D.C.; Gautam, D.; Gillespie, K.A.; Chappell, W.H.; Moody, C.A. Productive replication of human papillomavirus 31 requires DNA repair factor NBS1. J. Virol. 2014, 88, 8528-8544. [CrossRef] [PubMed]

136. Moody, C.A.; Fradet-Turcotte, A.; Archambault, J.; Laimins, L.A. Human papillomaviruses activate caspases upon epithelial differentiation to induce viral genome amplification. Proc. Natl. Acad. Sci. USA 2007, 104, 19541-19546. [CrossRef] [PubMed] 
137. Sakakibara, N.; Chen, D.; Jang, M.K.; Kang, D.W.; Luecke, H.F.; Wu, S.Y.; Chiang, C.M.; McBride, A.A. Brd4 is displaced from HPV replication factories as they expand and amplify viral DNA. PLoS Pathog. 2013, 9, e1003777. [CrossRef] [PubMed]

138. Gillespie, K.A.; Mehta, K.P.; Laimins, L.A.; Moody, C.A. Human papillomaviruses recruit cellular DNA repair and homologous recombination factors to viral replication centers. J. Virol. 2012, 86, 9520-9526. [CrossRef] [PubMed]

139. Langsfeld, E.S.; Bodily, J.M.; Laimins, L.A. The deacetylase sirtuin 1 regulates human papillomavirus replication by modulating histone acetylation and recruitment of DNA damage factors NBS1 and RAD51 to viral genomes. PLoS Pathog. 2015, 11, e1005181. [CrossRef] [PubMed]

140. Flores, E.R.; Lambert, P.F. Evidence for a switch in the mode of human papillomavirus type 16 DNA replication during the viral life cycle. J. Virol. 1997, 71, 7167-7179. [PubMed]

141. Hirano, T. SMC proteins and chromosome mechanics: From bacteria to humans. Philos. Trans. R. Soc. Lond. B Biol. Sci. 2005, 360, 507-514. [CrossRef] [PubMed]

142. Johnson, B.A.; Aloor, H.L.; Moody, C.A. The RB binding domain of Hpv31 E7 is required to maintain high levels of DNA repair factors in infected cells. Virology 2017, 500, 22-34. [CrossRef] [PubMed]

143. Hong, S.; Laimins, L.A. The JAK-STAT transcriptional regulator, STAT-5, activates the ATM DNA damage pathway to induce Hpv 31 genome amplification upon epithelial differentiation. PLoS Pathog. 2013, 9, e1003295. [CrossRef] [PubMed]

144. Hong, S.; Dutta, A.; Laimins, L.A. The acetyltransferase tip60 is a critical regulator of the differentiation-dependent amplification of human papillomaviruses. J. Virol. 2015, 89, 4668-4675. [CrossRef] [PubMed]

145. Reinson, T.; Toots, M.; Kadaja, M.; Pipitch, R.; Allik, M.; Ustav, E.; Ustav, M. Engagement of the ATR-dependent DNA damage response at the human papillomavirus 18 replication centers during the initial amplification. J. Virol. 2013, 87, 951-964. [CrossRef] [PubMed]

146. Fradet-Turcotte, A.; Bergeron-Labrecque, F.; Moody, C.A.; Lehoux, M.; Laimins, L.A.; Archambault, J. Nuclear accumulation of the papillomavirus E1 helicase blocks S-phase progression and triggers an ATM-dependent DNA damage response. J. Virol. 2011, 85, 8996-9012. [CrossRef] [PubMed]

147. Gauson, E.J.; Donaldson, M.M.; Dornan, E.S.; Wang, X.; Bristol, M.; Bodily, J.M.; Morgan, I.M. Evidence supporting a role for TOPBP1 and BRD4 in the initiation but not continuation of human papillomavirus 16 E1/E2-mediated DNA replication. J. Virol. 2015, 89, 4980-4991. [CrossRef] [PubMed]

148. Galloway, D.A.; Laimins, L.A. Human papillomaviruses: Shared and distinct pathways for pathogenesis. Curr. Opin. Virol. 2015, 14, 87-92. [CrossRef] [PubMed]

149. Papamichos-Chronakis, M.; Peterson, C.L. Chromatin and the genome integrity network. Nat. Rev. Genet. 2013, 14, 62-75. [CrossRef] [PubMed]

150. Polo, S.E.; Jackson, S.P. Dynamics of DNA damage response proteins at DNA breaks: A focus on protein modifications. Genes Dev. 2011, 25, 409-433. [CrossRef] [PubMed]

151. Van Attikum, H.; Gasser, S.M. Crosstalk between histone modifications during the DNA damage response. Trends Cell Biol. 2009, 19, 207-217. [CrossRef] [PubMed]

152. Gautam, D.; Moody, C.A. Impact of the DNA damage response on human papillomavirus chromatin. PLoS Pathog. 2016, 12, e1005613. [CrossRef] [PubMed]

153. Oberdoerffer, P.; Michan, S.; McVay, M.; Mostoslavsky, R.; Vann, J.; Park, S.K.; Hartlerode, A.; Stegmuller, J.; Hafner, A.; Loerch, P.; et al. SIRT1 redistribution on chromatin promotes genomic stability but alters gene expression during aging. Cell 2008, 135, 907-918. [CrossRef] [PubMed]

154. Tang, J.; Cho, N.W.; Cui, G.; Manion, E.M.; Shanbhag, N.M.; Botuyan, M.V.; Mer, G.; Greenberg, R.A. Acetylation limits 53BP1 association with damaged chromatin to promote homologous recombination. Nat. Struct. Mol. Biol. 2013, 20, 317-325. [CrossRef] [PubMed]

155. Saldivar, J.C.; Cortez, D.; Cimprich, K.A. The essential kinase ATR: Ensuring faithful duplication of a challenging genome. Nat. Rev. Mol. Cell Biol. 2017. [CrossRef] [PubMed]

156. Spardy, N.; Covella, K.; Cha, E.; Hoskins, E.E.; Wells, S.I.; Duensing, A.; Duensing, S. Human papillomavirus 16 E7 oncoprotein attenuates DNA damage checkpoint control by increasing the proteolytic turnover of claspin. Cancer Res. 2009, 69, 7022-7029. [CrossRef] [PubMed]

157. Bester, A.C.; Roniger, M.; Oren, Y.S.; Im, M.M.; Sarni, D.; Chaoat, M.; Bensimon, A.; Zamir, G.; Shewach, D.S.; Kerem, B. Nucleotide deficiency promotes genomic instability in early stages of cancer development. Cell 2011, 145, 435-446. [CrossRef] [PubMed] 
158. Ellison, V.; Stillman, B. Biochemical characterization of DNA damage checkpoint complexes: Clamp loader and clamp complexes with specificity for 5' recessed DNA. PLoS Biol. 2003, 1, E33. [CrossRef] [PubMed]

159. Zou, L.; Liu, D.; Elledge, S.J. Replication protein a-mediated recruitment and activation of RAD17 complexes. Proc. Natl. Acad. Sci. USA 2003, 100, 13827-13832. [CrossRef] [PubMed]

160. Mordes, D.A.; Glick, G.G.; Zhao, R.; Cortez, D. TOPBP1 activates ATR through ATRIP and a PIKK regulatory domain. Genes Dev. 2008, 22, 1478-1489. [CrossRef] [PubMed]

161. Edwards, T.G.; Helmus, M.J.; Koeller, K.; Bashkin, J.K.; Fisher, C. Human papillomavirus episome stability is reduced by aphidicolin and controlled by DNA damage response pathways. J. Virol. 2013, 87, 3979-3989. [CrossRef] [PubMed]

162. Liu, S.; Opiyo, S.O.; Manthey, K.; Glanzer, J.G.; Ashley, A.K.; Amerin, C.; Troksa, K.; Shrivastav, M.; Nickoloff, J.A.; Oakley, G.G. Distinct roles for DNA-PK, ATM and ATR in RPA phosphorylation and checkpoint activation in response to replication stress. Nucleic Acids Res. 2012, 40, 10780-10794. [CrossRef] [PubMed]

163. Bertoli, C.; Klier, S.; McGowan, C.; Wittenberg, C.; de Bruin, R.A. CHK1 inhibits E2F6 repressor function in response to replication stress to maintain cell-cycle transcription. Curr. Biol. 2013, 23, 1629-1637. [CrossRef] [PubMed]

164. Buisson, R.; Boisvert, J.L.; Benes, C.H.; Zou, L. Distinct but concerted roles of ATR, DNA-PK, and CHK1 in countering replication stress during S phase. Mol. Cell 2015, 59, 1011-1024. [CrossRef] [PubMed]

165. Murga, M.; Campaner, S.; Lopez-Contreras, A.J.; Toledo, L.I.; Soria, R.; Montana, M.F.; D'Artista, L.; Schleker, T.; Guerra, C.; Garcia, E.; et al. Exploiting oncogene-induced replicative stress for the selective killing of Myc-driven tumors. Nat. Struct. Mol. Biol. 2011, 18, 1331-1335. [CrossRef] [PubMed]

166. Toledo, L.I.; Murga, M.; Zur, R.; Soria, R.; Rodriguez, A.; Martinez, S.; Oyarzabal, J.; Pastor, J.; Bischoff, J.R.; Fernandez-Capetillo, O. A cell-based screen identifies ATR inhibitors with synthetic lethal properties for cancer-associated mutations. Nat. Struct. Mol. Biol. 2011, 18, 721-727. [CrossRef] [PubMed]

167. Nordlund, P.; Reichard, P. Ribonucleotide reductases. Annu. Rev. Biochem. 2006, 75, 681-706. [CrossRef] [PubMed]

168. Jang, M.K.; Shen, K.; McBride, A.A. Papillomavirus genomes associate with BRD4 to replicate at fragile sites in the host genome. PLoS Pathog. 2014, 10, e1004117. [CrossRef] [PubMed]

169. Sarni, D.; Kerem, B. The complex nature of fragile site plasticity and its importance in cancer. Curr. Opin. Cell Biol. 2016, 40, 131-136. [CrossRef] [PubMed]

170. Gao, G.; Johnson, S.H.; Vasmatzis, G.; Pauley, C.E.; Tombers, N.M.; Kasperbauer, J.L.; Smith, D.I. Common fragile sites (CFS) and extremely large CFS genes are targets for human papillomavirus integrations and chromosome rearrangements in oropharyngeal squamous cell carcinoma. Genes Chromosomes Cancer 2017, 56, 59-74. [CrossRef] [PubMed]

171. Bodelon, C.; Untereiner, M.E.; Machiela, M.J.; Vinokurova, S.; Wentzensen, N. Genomic characterization of viral integration sites in HPV-related cancers. Int. J. Cancer 2016, 139, 2001-2011. [CrossRef] [PubMed]

172. Thorland, E.C.; Myers, S.L.; Persing, D.H.; Sarkar, G.; McGovern, R.M.; Gostout, B.S.; Smith, D.I. Human papillomavirus type 16 integrations in cervical tumors frequently occur in common fragile sites. Cancer Res. 2000, 60, 5916-5921. [PubMed]

173. Choo, K.B.; Chen, C.M.; Han, C.P.; Cheng, W.T.; Au, L.C. Molecular analysis of cellular loci disrupted by papillomavirus 16 integration in cervical cancer: Frequent viral integration in topologically destabilized and transcriptionally active chromosomal regions. J. Med. Virol. 1996, 49, 15-22. [CrossRef]

174. McBride, A.A.; Warburton, A. The role of integration in oncogenic progression of HPV-associated cancers. PLoS Pathog. 2017, 13, e1006211. [CrossRef] [PubMed]

175. McBride, A.A. Playing with fire: Consequences of human papillomavirus DNA replication adjacent to genetically unstable regions of host chromatin. Curr. Opin. Virol. 2017, 26, 63-68. [CrossRef] [PubMed]

176. Wallace, N.A.; Khanal, S.; Robinson, K.L.; Wendel, S.O.; Messer, J.J.; Galloway, D.A. High risk $\alpha$ papillomavirus oncogenes impair the homologous recombination pathway. J. Virol. 2017. [CrossRef] [PubMed]

(C) 2017 by the author. Licensee MDPI, Basel, Switzerland. This article is an open access article distributed under the terms and conditions of the Creative Commons Attribution (CC BY) license (http://creativecommons.org/licenses/by/4.0/). 